\title{
Linking forms of inbound open innovation to a driver-based typology of environmental innovation: Evidence from French manufacturing firms
}

\author{
Li-Ying, Jason; Mothe, Caroline; Nguyen, Thi Thuc Uyen
}

Published in:

Technological Forecasting and Social Change

Link to article, DOI:

10.1016/j.techfore.2017.05.031

Publication date:

2018

Document Version

Peer reviewed version

Link back to DTU Orbit

Citation (APA):

Li-Ying, J., Mothe, C., \& Nguyen, T. T. U. (2018). Linking forms of inbound open innovation to a driver-based typology of environmental innovation: Evidence from French manufacturing firms. Technological Forecasting and Social Change, 135, 51-63. https://doi.org/10.1016/j.techfore.2017.05.031

\section{General rights}

Copyright and moral rights for the publications made accessible in the public portal are retained by the authors and/or other copyright owners and it is a condition of accessing publications that users recognise and abide by the legal requirements associated with these rights.

- Users may download and print one copy of any publication from the public portal for the purpose of private study or research.

- You may not further distribute the material or use it for any profit-making activity or commercial gain

- You may freely distribute the URL identifying the publication in the public portal 


\title{
Please cite this article as:
}

Li-Ying, J., Mothe, C., \& Nguyen, T. T. U. (2017). Linking forms of inbound open innovation to a driver-based typology of environmental innovation: Evidence from French manufacturing firms. Technological Forecasting and Social Change. Online early view, https://doi.org/10.1016/j.techfore.2017.05.031

\section{Linking forms of inbound open innovation to a driver-based typology of environmental innovation: Evidence from French manufacturing firms}

Jason Li-Ying

DTU Management Engineering Department, Technical University of Denmark, Denmark

yinli@dtu.dk

Caroline Mothe ${ }^{1}$

University Savoie Mont Blanc, France

Caroline.Mothe@univ-smb.fr

Uyen T. Nguyen-Thi

Luxembourg Institute of Socio-Economic Research (LISER), Luxembourg

thithucuyen.nguyen@liser.lu

\begin{abstract}
Environmental innovation (EI) research has not yet clarified how different forms of inbound innovation might exert effects. The current article proposes four driver-based EI types according to two main dimensions: compliance versus voluntary and own value capture versus customer value capture. With a problem-solving perspective, we develop links from different forms of inbound innovation to various types of EI and test the related hypotheses with two waves of the French Community Innovation Survey. On a short-term basis, R\&D cooperation and technology acquisition correlate positively with all four types of EI, but over time, persistent $\mathrm{R} \& \mathrm{D}$ cooperation and technology acquisition are associated with EI only at the production stage, according to voluntary/strategic or compliance drivers. Inbound innovation enables quick responses to market demands for EI in the final use stage.
\end{abstract}

\footnotetext{
${ }^{1}$ Corresponding author
} 
Keywords: Environmental innovation; Inbound open innovation; R\&D acquisition; R\&D cooperation; Technology sourcing; Value creation and capture

\section{Introduction}

Environmental innovations (EI), defined as the production, assimilation or exploitation of a product, production process, or methods that is novel to an organization and results in a reduction of environmental risk, pollution, and other negative impacts of resources use (including energy use), compared to relevant alternatives (Kemp and Pearson, 2008, p. 7), has captured increasing attention from researchers due to its importance to firm performance and for the sustainable environment at large (Ambec et al., 2013; Gilli et al., 2014; Marin and Lotti, 2017). Although firms are developing and adopting more EI, empirical studies generally either do not distinguish different types of EI (e.g., De Marchi, 2012; Jaffe and Palmer, 1997; Kammerer, 2009), or simply classify EI according to their technical outcomes (e.g., reduced material uses, $\mathrm{CO}_{2}$ emission, energy consumption, water, soil, noise) (e.g., Ghisetti et al., 2015; Horbach et al., 2012; Wagner, 2008). Findings obtained with these approaches can be useful to some extent, but they overlook firms' motivations to engage in EI, which have a different locus of value capture.

First, when firms perceive a problem or challenge, they are motivated to innovate (Cyert and March, 1963; Felin and Zenger, 2014). These perceived problems might entail economic underperformance, demanding customer requirements, or new regulatory requirements (Horbach, 2008; Porter and van der Linde, 1995). That is, in addition to market pull and technology push trends that motivate firms to introduce EI voluntarily, regulatory forces likely drive EI as well (Porter and van der Linde, 1995; De Marchi, 2012; Horbach et al., 2012; Kammerer, 2009). We thus need to distinguish EI with respect to voluntary versus compliance motivations, as called for in prior literature (Bossle et al., 2016; Hojnik and Ruzzier, 2016). 
Second, in addition to their economic and environmental externalities, similar to any innovation (De Marchi, 2012), EI are supposed to create value that various agents can capture (Lepak et al., 2007). Prior literature draws a rather subtle line between EI that are developed and adopted by the focal firm and those that emerge as product or process innovations by a distinct firm that introduces them to the market, to be adopted by other firms (Hojnik and Ruzzier, 2016; Bossle et al., 2016; Arora et al., 2014). The former usually have clear cost or pollution reduction benefits for the focal firm; the latter create new value propositions for customers (Kammerer, 2009). The distinct locus of value capture then may provide different drivers for firms to innovate (Bowman and Ambrosini, 2000).

Our focus on EI, in terms of product and process innovations, in turn suggests that open approaches to innovation might have varying implications for different types of EI that require firms to engage in external knowledge sourcing and collaboration (Chesbrough, 2003; West and Bogers, 2015). For example, with an inbound approach, firms access external technology sources for their innovation (Dahlander and Gann, 2010; Enkel et al., 2009), which can be particularly beneficial for EI (Ghisetti et al., 2015; Horbach et al., 2012). A firm's access to external technologies often takes different forms, such as an ad hoc acquisition of external knowledge through licensing, external R\&D, or formalized R\&D cooperation agreements. These forms each require different levels of control and coordination (Gulati and Singh, 1998; van der Vrande et al., 2006), though to our knowledge, little research has considered the effect of different forms of inbound innovation on firms' EI (Dahlander and Gann, 2008; West and Bogers, 2015).

To define which inbound innovation strategies firms deploy for different types of EI, we consider the two key dimensions: motivations (compliance versus voluntary) and locus of value capture/adoption (own value capture versus customer value capture). Accordingly, we formulate a four-way, driver-based typology of EI that constitutes an original contribution to 
the extant literature. We investigate the influence of different forms of inbound open innovation on the introduction of different types of EI. Data from two waves of the French Community Innovation Survey (CIS) during 2004-2008 provide the empirical evidence.

In the next section, we review the state-of-the-art literature pertaining to the drivers of EI and open innovation. Using our new two-dimensional, driver-based typology for EI, we identify four profiles of firms engaged in EI. Next, we develop hypotheses about the implications of inbound innovation for the different EI profiles. After we present the data and methods, we discuss the results. Finally, we highlight our contributions, pinpoint some limitations, and suggest future research directions.

\section{Theoretical background and hypothesis development}

\subsection{Drivers of environmental innovation}

Researchers have paid substantial attention to what leads firms to develop and adopt EI, using rubrics such as motivations, drivers, and stimuli (see Triguero et al., 2013; Bossle et al., 2016; Hojnik and Ruzzier, 2016). Similar to any other technological innovations, EI may be developed and adopted by firms in response to technology pushes (Geffen and Rothenberg, 2000) and market pulls (De Marchi, 2012; Horbach et al., 2012). The new technologies must find applications with clear value propositions for the target market. However, EI are also reinforced by regulatory forces (Horbach et al., 2012; Kammerer, 2009). According to the Porter hypothesis (Porter and van der Linde, 1995), increasingly stringent environmental regulations give firms an incentive to develop and adopt new technologies and processes, with positive economic and environmental externalities (Ambec et al., 2013; Jaffe and Palmer, 1997). Both current and anticipated regulations can drive firms to engage in EI and ultimately create competitive advantages (Kemp and Pontoglio, 2011). In their review of factors that trigger EI, Hojnik and Ruzzier (2016) find that regulations are among the most frequently reported drivers. 
Well-designed and executed regulations may trigger the introduction of EI, which can enhance firms' business performance in the long run, but the cost of compliance can be high in the short term by reducing firms' productivity and performance (Ambec et al., 2013; Marin and Lotti, 2017). In this sense, some firms adopt EI to comply with regulations and are compelled to create new solutions to reduce negative environmental impacts, but others voluntarily explore the boundaries of new technologies and methods as part of their proactive environmental strategies to stay ahead of regulations (Buysse and Verbeke, 2003; Kemp and Pearson, 2008). These two categories of firms would exhibit different propensities to introduce EI (Bocquet et al., 2013). Firms that embrace voluntary activities (e.g., environmental management systems) likely achieve sustainable competitive advantages ahead of their competitors (Frondel et al., 2008; Wagner, 2008), while also mitigating the pressures from environmental regulations (Eiadat et al., 2008). Therefore, we conceptually distinguish compliance and voluntary drivers of EI. This distinction also appears in a previous empirical study of the link between EI and firm profitability (Rexhäuser and Rammer, 2014).

Regardless of whether they are compliance or voluntarily driven, EI are supposed to create various benefits, such as reducing pollution, resource consumption, and energy use, all of which, in turn, may lead to cost savings and improved business performance (Kemp and Pearson, 2008; Bossle et al., 2016). However, there is also a distinction-which has not been highlighted explicitly in prior literature-between EI with environmental and economic benefits created for and captured by an innovating firm's customers and EI that are developed and adopted by the focal innovating firm itself. From an innovation adoption perspective (Cooper, 1998), both cases contribute to the diffusion of EI, but the former is adopted by the market (customers as users), whereas the latter is adopted by the focal firm itself (users as innovators). 
Arora et al. (2014) illustrate an interesting case of the promotion of manufactured nanotechnology products (MNPs) that increased the resource and energy efficiency of construction materials in the US. Various industrial firms and research institutes held key technologies underlying these MNPs, for which many patents were filed. The EI based on these MNPs were adopted widely in the building construction industry, which consists of a large network of architects, engineering firms, general contractors, property owners, and lead users. In most cases, firms that own the key technologies developed and introduced relevant EI for the entire building construction industry, as an application market. In this case, customers must be convinced that the EI provide advantages, in terms of cost or energy savings, improved quality, better disposal solutions, or reduced health impacts (Kammerer, 2009). That is, firms create value by introducing EI, whose environmental and economic value is captured by customers. In other cases, technology holders (innovators) may find MNPs useful for their own production processes, because they create environmental and economic benefits for the firms themselves. Self-adoption of EI makes perfect sense if the benefits of EI are obvious in the short run, because the innovating firm needs to offset its upfront development costs. These firms invest and introduce EI primarily to gain benefits for themselves, especially if the use value is high but the exchange value on the market is relatively low, whether due to competition or ineffective appropriation regimes (Lepak et al., 2007). These EI generally feature technologies that apply to the firm's own production, logistics, and disposal processes, which can be optimized and upgraded to improve its efficiency. From a resource-based view, such selfadopted EI can create a competitive advantage over competitors, due to its effective deployment of resources and related capabilities (Barney, 1991; Teece, 2007, 2014). Prior studies also show that firm profitability improves when its own resource efficiency increases, due to EI (Eiadat et al., 2008). Applying the Porter hypothesis, Rexhäuser and Rammer (2014) even suggest that it may be necessary to increase an innovating firm's own resource efficiency first, regardless of 
its motives for EI. Therefore, in line with the recent development in the literature (Hojnik and Ruzzier, 2016), we distinguish these two different mechanisms of innovation adoption and value capture, which we label market innovators and production innovators, respectively

By combining the compliance versus voluntary motivations with the distinction between market and production innovators, we propose a driver-based typology that specifies four nuanced profiles of driver-based EI. First, market innovators are obviously motivated by market pull factors, because market acceptance is key for their EI to be adopted (Kesidou and Demirel, 2012). Firms are generally motivated by customer demands to voluntarily develop innovative products and processes for the market to earn economic rents. Meanwhile, stringent regulations also push firms to introduce EI to the market, by providing information, setting standards, and reducing market uncertainty (Jaffe and Palmer, 1997; Porter and van der Linde, 1995). Second, production innovators are subject to both voluntary and regulation forces, such that they are motivated to capture the related benefits for themselves. Therefore, we can delineate four nuanced profiles of EI (see Figure 1):

- Compliance cleaner market innovators (compliance CMI) are driven by regulatory requirements and aim to create new value propositions through EI for customers in existing and new markets.

- Compliance cleaner production innovators (compliance CPI) come under compliance pressure and seek improved environmental performance and cost efficiency by adopting their own innovative products or processes.

- Strategic cleaner production innovators (strategic CPI) voluntarily explore EI opportunities that they can apply to their own production processes so they can achieve a leading position in terms of environmental performance and efficiency. 
- Strategic cleaner market innovators (strategic CMI) do not passively follow regulations but instead voluntarily explore market opportunities for customers who demand greater environmental performance and cost efficiency.

Insert Figure 1 here

\subsection{Inbound open innovation}

Technological innovation often requires searching for new knowledge that the firm can combine creatively with its existing technologies, because innovative opportunities often lie outside of firm boundaries. Driven by fierce market competition and rapid technological changes, firms increasingly use open innovation models that involve external actors and sources to enhance their innovative performance (Chesbrough, 2003). An inbound innovation approach, through which a firm extends its own knowledge base by searching, selecting, and integrating external knowledge from various external relationships, is a distinctive, generic mode of open innovation (Enkel et al., 2009; Li-Ying, 2016).

A well-established stream of literature considers the openness of firms' boundaryspanning activities and finds that firms investing in broader and deeper external knowledge searches may achieve a greater ability to innovate, compared with firms with closed innovation models or those that engage in narrow external knowledge searches (Laursen and Salter, 2006). Using the CIS data from the United Kingdom, Laursen and Salter (2006) find that a wide, diverse search strategy contributes to new opportunities for creation, but an overly broad search may be ineffective, due to firms' limited absorptive capacity and the increasing uncertainty associated with learning. Thus, an inverted U-shaped relationship between search breadth and firms' innovation performance has been suggested (Laursen and Salter, 2014; Li and Vanhaverbeke, 2009). These findings resonate with research into EI specifically. For example, Rennings and Rammer (2009) find that German firms search more broadly than other innovators when introducing energy and resource efficiency innovations. According to the CIS 
data from Germany and France, EI requires broad external knowledge searches (Horbach et al., 2012, 2013), but overly broad search can have negative effects (Ghisetti et al., 2015).

Moreover, an open innovation approach requires firms to govern their relationships with external knowledge partners, considering the risks and uncertainty associated with openness (Dahlander and Gann; 2010; Enkel et al., 2009; Huizingh, 2011). Designing and implementing appropriate forms of inbound innovation to control and coordinate external collaborative relationships thus may be a source of competitive advantage from a relational view (Dyer and Singh, 1998). When firms enter a collaborative relationship, governed by a contract, concerns arise about the potential coordination costs, or "the anticipated organizational complexity of decomposing tasks among partners along with ongoing coordination of activities to be completed jointly or individually across organizational boundaries and the related extent of communication and decisions that would be necessary" (Gulati and Singh, 1998, p. 782). When a knowledge-based collaboration involves high interdependence, high levels of control are needed to ensure superior task coordination.

In the research domain of EI, recent attention has been directed toward governance issues, within and across organizational boundaries (Ambec et al., 2014), but few empirical studies address the interplay of the various forms of external knowledge sourcing/collaborations and different types of EI. We suggest that the different driver-based types of EI require firms to select and implement appropriate collaboration forms, to ensure a sufficient level of coordination for inbound innovation. According to Hagedoorn (1993), when a firm needs to access external technologies, it has several choices: acquire technologies based on arm's-length contracts (e.g., purchasing and licensing), outsource R\&D to other organizations, or engage in R\&D cooperation (joint R\&D) with partners. Purchasing and licensing are pecuniary forms of inbound innovation; external $R \& D$ and $R \& D$ cooperation are non-pecuniary (Chesbrough, 2003; Dahlander and Gann, 2010). 
From a relational perspective, these forms of inbound innovation differ in the degree of control and coordination they require in terms of interfirm relationship-specific assets, knowledge-sharing routines, and complementarity (Dyer and Singh, 1998; Hagedoorn, 1993). First, the acquisition of external technology implies an arm's-length market exchange, requiring minimum interfirm relationship-specific assets, knowledge sharing, and coordination (Dahlander and Gann, 2010). In well-developed technology markets, firms can acquire external technologies through the purchase or licensing of patents, based on which they innovate further (Li-Ying and Wang, 2015; Li-Ying et al., 2013). A licensor may provide some licensees with technical know-how, but coordination remains limited.

Second, external $R \& D$ can be accessed through contractual knowledge alliances with specific research objectives. Compared with arm's-length market exchanges, external R\&D requires more relationship-specific assets and implies some knowledge sharing between the focal firm and the organization that conducts the external R\&D. Research shows that external R\&D is beneficial only if it exhibits some complementarity with the focal firm's internal knowledge (Cassiman and Veugelers, 2006).

Third, $R \& D$ cooperation might take the form of joint ventures, equity (minority holding) or non-equity alliances between firms, or agreements with universities and research institutes (Wang and Li-Ying, 2015). It demands a high level of relationship-specific assets, knowledge sharing, and complementarity, and it invokes high coordination costs (Brockhoff, 1992). Active mutual involvement in collaborative $R \& D$ activities is both the reason for and the result of interactive knowledge sharing and exploration of complementary assets across collaborators (Robertson and Gatignon, 1998). It implies a learning race, such that the appropriation concerns demand highly protective modes of control.

Mixed evidence is available about the relationship between the various forms of inbound innovation and EI. Using the Spanish CIS from 2007, De Marchi (2012) finds no significant 
effect of external R\&D on EI but a positive effect of R\&D cooperation. Firms engaged in external R\&D seemingly have a lower probability of introducing energy and material efficiency process innovations (Bönte and Dienes, 2013). A negative effect of external R\&D emerges for process innovations with environmental benefits in the energy, dangerous materials, and recycling industries, but $R \& D$ cooperation has a positive effect on EI for firms dealing with dangerous substances (Horbach et al., 2013). Yet European firms that collaborate in networks with universities and public institutions are essential drivers of all types of EI (Cainelli et al., 2011; Triguero et al., 2013). We argue that these mixed results might be clarified by adopting the lens of our proposed driver-based typology of EI.

\subsection{Hypotheses}

The behavioral theory of organization posits that the root cause that leads firms to innovate is an enacted problem situation, defined by a firm's current or anticipated underperformance (Cyert and March, 1963). A problem-solving perspective thus can be used to develop links between forms of inbound innovation and types of EI (Felin and Zenger, 2014). We borrow Felin and Zenger's (2014) logic to identify key attributes of the problems embedded in different driver-based types of EI, as well as to propose arguments for why a particular form of inbound innovation may be most suitable to cope with a complex problem related to knowledge sharing.

Firms involved in voluntary types of EI (strategic CPI and CMI) proactively define future problems (Sharma and Vredenburg, 1998) and explore both technological domains and market applications (Porter and van der Linde, 1996). Strategic CPI seek to adopt new materials, equipment, and technologies into their own business processes (manufacturing, logistics, disposal, energy consumption), and potential environmental and economic benefits are clearly anticipated for the innovating firm. These firms face high levels of technical and operational difficulty. For example, reducing energy waste by $5 \%$ beyond a regulatory standard 
may seem straightforward, but a great deal of hidden technological knowledge must be explored to resolve such a complex problem. As strategic CPI are developed ahead of competitors, not many ready-to-use technologies and knowhow are available to be acquired from the market. Therefore, firms pursue specific investments in collaborative R\&D. Similarly, as strategic CMI create new value propositions for customers, firms confront greater problem complexity, so they need to explore both new technologies and markets, and they confront substantial unknown information.

Overall, firms engaged in voluntary EI often have no prior art to use, and because their new practices (and the positive consequences) are not explicitly required by law, ready-to-use technical knowledge is not directly available to acquire. Therefore, firms engaging in voluntary types of EI tend to invest in specific assets, engage in interorganizational learning, and co-create new practices with external R\&D partners. Sequential and reciprocal forms of coordination can help ensure relational rents for such voluntary EI, so R\&D cooperation is an appropriate form of inbound innovation (Hagedoorn, 1993). Therefore, we expect both R\&D cooperation and external R\&D to be suitable for voluntary EI (strategic CPI and CMI).

Hypothesis 1: R\&D cooperation is positively associated with voluntary EI.

Hypothesis 2: External R\&D is positively associated with voluntary EI.

Compliance-based EI instead entails relatively simpler problems, because by default, a compliance-oriented regulatory design must incorporate monitoring and enforcement of that compliance (Parker, 2000). The objectives, market applications, and performance measures likely are well defined by compliance-oriented regulations and known to firms, so these firms can search for existing solutions in technology markets. They tend to prefer to license or purchase technologies that are already available, which enables them to avoid committing relationship-specific assets or engaging in a potential learning race with external R\&D partners (Das and Teng, 2000). Compliance-oriented regulations also provide a clear timeline for firms, 
allowing them to formulate foreseeable compliance objectives. According to Porter's hypothesis, the benefits of EI triggered by regulations might take time to offset the costs of innovation (Porter and van der Linde, 1996; Ambec et al., 2013). Here, rational decision making suggests the acquisition of external knowledge, which offers an effective solution and achieves objectives, without high coordination costs (Hagedoorn, 1993). Thus,

Hypotheses 3: Acquisition of external technology is positively associated with compliance-based EI.

For both compliance and voluntary types of EI, the locus of value capture (or who adopts the EI) may differ. Theoretically, customer value capture EI (relative to own value capture EI) creates use value that needs to be attached to realizable exchange value, so it is a relatively more complex problem (Bowman and Ambrosini, 2000). Customer value capture EI involves technological knowledge, as well as product- and market-related knowledge, so market uncertainty becomes an additional dimension of uncertainty. The high level of uncertainty, coupled with a lack of guidance for information gathering and an implementation agenda provided by regulations, lessens the motivation for firms to invest in specific assets in mutual learning that is typically associated with R\&D cooperation (Kesidou and Demirel, 2012). In contrast, EI for own value capture and adoption has relatively clear perspectives on the environmental and economic benefits for the focal firm, making greater commitments of specific assets and knowledge sharing with knowledge partners attractive methods for drawing on external knowledge (Lepak et al., 2007). Following this logic, since R\&D cooperation should have a positive association with voluntary EI (including strategic CPI and strategic CMI), strategic CPI that justify the need to coordinate tightly with knowledge partners—such as by engaging in knowledge sharing, interactive learning, and co-creation (Robertson and Gatignon, 1998) — should have a more evident, positive relationship with R\&D cooperation, 
compared with strategic CMI that face greater problem complexity and uncertainty. Therefore, we hypothesize

Hypothesis 4: The positive effect of R\&D cooperation is stronger on strategic CPI EI (own-value capture) than on strategic CMI EI (customer-value capture).

As we predicted in Hypothesis 2, external R\&D is appropriate for voluntary EI in general, but the question is whether there is a reason to expect a difference between strategic CPI and strategic CMI. The effect of external R\&D on innovation in the literature is controversial. Most scholars note the complementarity between internal and external R\&D (e.g. Veugelers and Cassiman. 1999; Hagedoorn and Wang, 2012; Ceccagnoli et al., 2014), but they offer inconclusive results. External R\&D matters for innovation as a complementary input in product innovation (Ganotakis and Love, 2012). Frank et al. (2016) show that a marketorientation innovation strategy prioritizes external R\&D activities, which has a positive effect on innovation output. For firms that increasingly rely on external $R \& D$ activities, innovative performance improves, but only up to a certain point (Berchicci, 2013).

Compared with own value capture EI, firms that engage in EI for customer value may experience greater demand to identify complementary resources and capabilities that are not necessary to be integrated and coordinated with a firm's internal knowledge base (Cassiman and Veugelers, 2006). Therefore, we argue that strategic CMI, compared with strategic CPI, is probably better suited to external $R \& D$, because it is important to have external $R \& D$ knowledge that is close to the market and reflects local needs. In contrast, external R\&D deployed for strategic CMI inevitably faces the challenge of translating the focal firm's performance objectives to the external $R \& D$ partner and integrating external $R \& D$ solutions into the focal firm's internal processes (Du et al., 2014). Therefore, we predict

Hypothesis 5: The positive effect of external R\&D is stronger on strategic CMI EI (customer-value capture) than on strategic CPI EI (own-value capture). 
As we noted in relation to Hypothesis 3, when they face regulatory pressure, firms are expected to acquire external technologies to minimize the costs of compliance. As to compliance-based EI, compliance CPI encounters the lowest level of problem complexity: The problems are defined by law and the regulations usually provide guidance with regard to performance measures, standards, and even potentially the supplier network structure (e.g., the MNPs case discussed above in Arora et al., 2014). The solution is to create environmental and efficiency benefits for the firm, which usually require solving only some technical uncertainties, without risky market exploration. The bottom line is to find ways to enhance the firm's own productivity by adopting its own EI (Marin and Lotti, 2017). Thus, the acquisition of external technologies governed by arm's-length contractual relationships is the most suitable form to obtain technical solutions. In contrast, firms that develop compliance CMI need to consider the specifications required by the regulations, which not only concern a firm's own production process but also govern customers' operations. For example, when the EU banned potentially hazardous chemicals used in children's toys in 2005, many Chinese toy manufacturers were forced to consider compliance CMI but found it relatively difficult to acquire new coating technologies simply by purchasing or licensing to solve the problem (see NBC News, World Environment 2005). With these arguments, we predict

Hypothesis 6: The positive effect of acquisition of external technology is stronger on compliance CPI EI (own value capture) than on compliance CMI (customer-value capture).

\section{Data and estimation strategy}

The European CIS follow a subject approach and use the firm as a statistical unit (rather than an individual innovation). They combine census and stratified sampling methods for each wave. The stratum variables are activity and size, and data collection includes both innovators and non-innovators. For statistical consistency, we draw on two successive waves. That is, we use 
firm-level data from two waves of the French CIS: CIS6 (2004-2006) and CIS8 (2006-2008), provided by the French Institute of Statistics and collected by the Industrial Studies and Statistics Office. Information about environmental innovation is available only in CIS8, but all other data are available in both versions of the French CIS. Our dependent variables (i.e., driverbased types of EI) thus are measured using only information from CIS8, but the independent variables can be observed for both CIS6 and CIS8. The final sample includes only firms that responded to both CIS6 and CIS8. It thus takes the characteristics of a balanced panel, containing 1,023 manufacturing firms. This approach has implications for our model specifications, as we explain subsequently (see Section 3.4).

The sector composition and size distribution of the final sample did not vary substantially across periods. All firms in our sample are large (more than 250 employees). More than half of the sample (54\%) consists of low or medium-low technology firms (according to the $\mathrm{NACE}^{2}$ classification), operating in sectors such as plastics, metals, food, textiles, and wood. The remainder of the sample (46\%) features high and medium-high technology firms, operating in industries such as electronics, instruments, and chemicals.

\subsection{Dependent variables}

To determine which forms of inbound innovation may influence the likelihood of environmental innovations, we categorize the drivers and the locus of value capture. To collect information related to innovations that generate environmental benefits, we identify firms that are product/process innovators and that introduced new or significantly improved products/processes with environmental effects from the CIS8, which contains information on EI during 2006-2008. We define product and process innovators as firms that introduced

\footnotetext{
${ }^{2}$ NACE is the statistical classification of economic activities in the European Community, used by all member states. We classified manufacturing industries according to their global technological intensity with NACE Revision 1.1 for the $\mathrm{t}-1$ period, whereas $\mathrm{t}$ was covered by NACE Revision 2, according to the Eurostat classification (http://epp.eurostat.ec.europa.eu/cache/ITY_SDDS/Annexes/hrst_st_esms_an9.pdf).
} 
goods/services, production processes, or methods of distribution that were new or significantly improved with respect to fundamental characteristics, technical specifications, incorporated software, other immaterial components, intended uses, or user friendliness. In this period, $42 \%$ of firms in France's manufacturing industry were product innovators.

In addition, CIS8 enables us to identify firms that have introduced innovations with environmental effects. An EI is a new or significantly improved product, process, organizational method, or marketing method that creates environmental benefits compared with alternatives. Firms reported whether they introduced different types of EI at the production or final use stage. With this information, we establish a subsample of firms that have introduced product innovations and report environmental impacts in either the production or final use stages. $^{3}$

In addition, to define compliance versus strategic EI, we identify elements that motivate firms to introduce EI, classified as either environmental regulations or other motives, using questions in CIS8. The environmental regulation variables include (1) existing regulations or taxes on pollution (question 10.2.1 in CIS) and (2) expected environmental financial regulations, environmental codes, and agreements for good practices in the sector (question 10.2.2 in CIS). On the basis of these two motives, we construct a binary Compliance variable, equal to 1 if firms introduced EI in response to at least one existing or expected environmental regulation, and 0 otherwise. The other objectives for introducing EI were (1) financial, such as benefiting from grants, subsidies, or other financial incentives (question 10.2.3 of CIS); (2) in response to current and expected market demand from customers for environmental products or services (question 10.2.4 of CIS); (3) voluntary codes or agreements for environmental good

\footnotetext{
${ }^{3}$ The EI at the production stage included (1) reduced material use per unit of output; (2) reduced energy use per unit of output; (3) reduced $\mathrm{CO}_{2}$ footprint (total $\mathrm{CO}_{2}$ production) by the enterprise; (4) replaced materials with less polluting or hazardous substitutes; (5) reduced soil, water, noise, or air pollution; and (6) recycled waste, water, or materials. The EI at the final use stage included (7) reduced energy use; (8) reduced air, water, soil or noise pollution; and (9) improved recycling of product after use.
} 
practices within the sector (question 10.2.5 of CIS); and (4) control procedures for regularly identifying and reducing environmental impacts, such as environmental audits, environmental performance goals, or ISO 14001 certifications (question 10.3 in CIS). Using these four motives, we build a binary Voluntary variable, equal to 1 if firms introduce EI in response to at least one of these motives, and 0 otherwise.

Next, we use this coding for compliance and voluntary EI and combine it with the information in the CIS data about EI at the production and use stages to formulate four profiles of driver-based EI. This approach allows us to operationalize four dependent variables (see Appendixes 1-3 for the variable definitions and descriptive statistics):

- Compliance CPI is equal to 1 if a product innovation with environmental benefits in the production stage reflects compliance motives, and 0 otherwise $\left(45 \%\right.$ of the sample $\left.{ }^{4}\right)$.

- Strategic CPI is equal to 1 if an EI applies to the production stage and reflects voluntary motives, and 0 otherwise ( $56 \%$ of the sample).

- Compliance CMI takes a value of 1 if an EI refers to the final use stage and compliance motives, and 0 otherwise ( $41 \%$ of the sample).

- Strategic CMI is equal to 1 if the EI reflects the final use stage and voluntary motives, and 0 otherwise ( $33 \%$ of the sample).

\subsection{Independent variables}

Three main forms of inbound innovation are included in the CIS data. Similar to prior studies (e.g., Nieto and Santamaría, 2010), we operationalize them as binary variables. First, acquisition of external technology refers to the purchase or licensing of patents and nonpatented inventions, know-how, and other types of knowledge from other enterprises or

\footnotetext{
${ }^{4}$ The sum of four types is greater than $100 \%$, because these profiles are not mutually exclusive.
} 
organizations to develop new or significantly improved products and processes (binary variable). Second, external $R \& D$ is performed by other firms (including other enterprises or subsidiaries within the firm's own group) or public or private research organizations and then purchased by the firm. Third, $R \& D$ cooperation refers to active participation with other enterprises or non-commercial institutions in innovation activities.

\subsection{Control variables}

Regarding the impact of external technology search strategies on EI (Ghisetti et al., 2015), we consider the breadth of knowledge sources as a control variable, spanning three external sources of information to control for the scope of other knowledge sources: (1) market sourcing, or information from suppliers, clients, competitors, consultants, commercial labs, private $R \& D$ institutes, and other firms in the sector; (2) institutional sourcing, including that from universities, other higher education institutions, and government and public research institutes; and (3) other sources, such as patents, databases, trade literature, or fairs. We assign a value of 1 for each source if that source is crucial ${ }^{5}$ to the focal firm's innovation activities, and 0 otherwise. Similar to Ghisetti et al. (2015) and Laursen and Salter (2006), we use a count variable, with 0 indicating the use of no information sources and 3 for the use of all three technological external sources. To control for a possible nonlinear relationship between information sources and EI, we introduce the squared value of this breadth variable in the estimation model. We also control for the level of a firm's absorptive capacity by using Internal $R \& D$ as a proxy. Similar to Ghisetti et al. (2015), we control for the social integration mechanism (SIM), which equals 1 if departments within a firm in the same group are crucial sources of information for the firm's innovation process, and 0 otherwise.

\footnotetext{
${ }^{5}$ The question was: "How important to your enterprise's innovation activities were each of the following information sources?" The choices listed were internal, market, institutional, and other sources. Answers were ranked according to the degree of importance, from 0 ("not used") to 3 ("very crucial").
} 
Several other control variables may influence the firm's propensity to introduce EI. Belonging to group ( $80 \%$ of firms in our sample) is a binary variable, equal to 1 if the firm is part of a group. Public funding is equal to 1 if the firm has introduced an environmental innovation in response to the availability of government grants, subsidies, or other financial incentives, and 0 otherwise. Market geography accounts for market conditions, using a fourpoint Likert response scale $(1=$ local market, $2=$ national, $3=$ European, $4=$ global market $)$. Firm size is measured as the natural logarithm of the number of employees. Finally, to address technological levels, we introduce sector dummies from 1 to 4 to represent high-tech, mediumhigh-tech, medium-low-tech, and low-tech sectors, respectively. Appendix 3 provides the descriptive statistics for all the independent variables.

\subsection{Estimation strategy}

We seek to test for the probability of being an eco-innovator in period $t$, as a function of present and past inbound innovation activities. We thus account for temporal dimensions in the effect of openness on environmental innovation. As highlighted in the data description, information about environmental innovation is available only in CIS8, but all the explanatory variables appear in both waves. Therefore, even though the final merged sample has the characteristics of a balanced panel, we cannot apply panel econometric methods. The EI propensities are described by binary choice equations, so we used a bivariate Probit model with two equations that include all the explanatory variables. With this approach, we can investigate the likelihood of generating different types of driver-based EI, which might be conditional on the set of past, present, and continuous inbound innovations. We primarily test our hypotheses and report the results in reference to CIS8, with which we can test all the information for the dependent and independent variables and the relationships among them, because they were measured during the same time frame. As a robustness check, we also test the hypotheses with 
a data set that combines both CIS6 and CIS8. A time-lagged effect is assumed in these additional tests, as detailed in Appendixes 4 and 5.

\section{Results}

Table 1 presents the correlations among the variables; Table 2 contains the bivariate Probit estimation model for the impact of inbound innovation on the likelihood of types of EI.

\section{---- INSERT TABLES 1 AND 2 ABOUT HERE ----}

The results show that $R \& D$ cooperation is positively and significantly associated with the likelihood that a firm engages in voluntary EI in general $(\beta=.368, p<.01)$ and with strategic CPI $(\beta=.353, p<.01)$ and strategic CMI $(\beta=.233, p<.05)$ in particular, in support of Hypothesis 1 . However, the coefficients of external R\&D show no significant effects on any of the dependent variables, so we must reject Hypothesis 2. In support of Hypothesis 3, the acquisition of external technology is significantly and positively associated with compliancedriven EI in general $(\beta=.240, p<.05)$ and with compliance CPI $(\beta=.261, p<.01)$ and compliance CMI $(\beta=.200, p<.05)$ in particular.

With regard to our predictions for differentiating the effects of $R \& D$ cooperation on strategic CPI and strategic CMI in H4, we compare the positive and significant effects in two models (strategic CPI $\beta=.353, p<.01$; strategic CMI $\beta=.233, p<.05$ ). Following Laursen and Salter (2014), we ran a Wald test of the difference between the coefficients across two models, using the stacking data method from StataCorp (2009) to compare the strength of the effects of the variables across models. The results show that the coefficients are significantlyh different $(p=.072)$, in support of Hypothesis 4. Next, as we found that external R\&D had no effect on any types of EI, we do not consider Hypothesis 5 any further.

With respect to acquisition of external technology, the positive and significant effect is higher for compliance CPI than for compliance CMI $(\beta=.261, p<.01 ; \beta=.200, p<.05$, respectively). A Wald test of the difference between the coefficients, based on stacking data 
(StataCorp, 2009), shows that the coefficient for external technology acquisition is significantly larger for compliance CPI than for compliance CMI $(p=.076)$, in support of Hypothesis 6.

Our dependent variables are observed at $\mathrm{t}$, so we also introduced the control variables at $\mathrm{t}$ in all three models, whether for cross-sectional data or time-lagged effects. Previous analyses provide evidence that information sources drive EI (e.g., Ghisetti et al., 2015). First, we control for the variety of information sources (breadth) (see Appendix 1) and confirm their role in determining a firm's capacities to introduce EI, reflecting a cumulative process of knowledge building. Diverse pieces of knowledge are fundamental to the development of EI. We observe a very strong association between all types of EI and three control variables: SIM, public funding, and firm size. Surprisingly though, internal R\&D indicates no positive effect.

To verify the robustness of these results based on cross-sectional data, we ran the estimation models with lagged effects of the independent variables as a robustness test. Specifically, we observed the forms of inbound innovation and other control variables in a previous time period. It is logical to consider these lagged effects of the independent variables, because access to external technologies may take time to produce new EI. Firms that accessed external technologies during 2004-2006 might start introducing EI during 2006-2008. By considering the lagged effects of independent variables, we also can reveal whether certain types of inbound innovation have short- or long-term effects. As the results in Appendix 4 show, when we use information from CIS6 to construct independent variables, R\&D cooperation has a positive, significant effect on voluntary EI, in support of Hypothesis 1, but neither external R\&D nor technology acquisition has an effect on the type of EI, so we cannot confirm Hypotheses 2 and 3. Furthermore, R\&D cooperation has a significant and positive effect on strategic CPI but no effect on strategic CMI, offering support for Hypothesis 4. However, the results regarding the differentiated effects of external $R \& D$ and technology acquisition (Hypotheses 5 and 6) find no support. When we use information from both CIS6 and CIS8 to 
measure the independent variables, the results in Appendix 5 exhibit a pattern identical to that we have described for Appendix 4.

Finally, as firms can implement EI in response to both compliance and voluntary motivations simultaneously or to only one motivation, we ran additional estimations for several additional dependent variables ${ }^{6}$ : dual EI (compliance + voluntary) and voluntary-only EI. (For the variable definitions and statistics, see Appendixes 1 and 2.) According to the estimation results in Appendix 6, R\&D cooperation and acquisition of external technologies both have positive, significant effects on dual strategy $\mathrm{EI}(\beta=.352, p<.01 ; \beta=.276, p<.01$, respectively $)$, but external R\&D has no effect. For voluntary-only EI, none of the inbound innovation forms exhibits significant effects. In detail, when we distinguish CPI and CMI, we find that R\&D cooperation and acquisition of external technologies have positive and significant effects only on dual strategy CPI $(\beta=.316, p<.01 ; \beta=.295, p<.01$, respectively $)$, and $\mathrm{R} \& \mathrm{D}$ cooperation has a positive and significant effect on dual strategy CMI $(\beta=.232, p<.05)$. These findings seem both surprising and reasonable, in that they show that firms rarely use inbound innovation to obtain external knowledge about EI without being driven by regulations. This result confirms, to some extent, the weak version of the Porter hypothesis, which states that regulatory forces enable firms to develop and adopt EI (Porter and van der Linder, 1995; Ambec et al., 2013). Furthermore, these results show that, of all the inbound innovation forms, R\&D cooperation is the most popular for firms that develop and adopt EI when they are driven by both regulatory forces and market pull.

\footnotetext{
${ }^{6} \mathrm{We}$ are grateful to an anonymous reviewer for the suggestion to test the difference between dual and voluntaryonly strategies. Only $3.6 \%$ of the firms in the sample introduced EI in response to regulations only, so we exclude this alternative dependent variable to test the effects of inbound innovation.
} 


\section{Discussion}

The proposed driver-based typology for EI combines a distinction between compliance versus voluntary motives with a differentiation of the locus of value capture (adoption). Four types of EI thus emerge. With this nuanced typology of EI, we can investigate the extent to which the likelihood of introducing a particular type of EI is associated with different forms of inbound innovation.

In a cross-sectional analysis, our results confirm most of our hypotheses. They also deserve some detailed discussion though. First, R\&D cooperation appears to be the most popular form of inbound innovation for both voluntary and compliance-based EI. This finding remains relatively consistent, regardless of the observation period used to operationalize the independent variable. With additional tests of firms' dual strategies, we also learn that in most cases, the positive effect of $R \& D$ cooperation pertains to firms that are motivated by both regulation and market pull simultaneously. When a firm is motivated by both drivers, it recognizes the strategic importance of the EI and relies on collaborative learning, investing specific assets to safeguard the results of its cooperation. In addition, R\&D cooperation, which demands a high level of investment, is coupled with the direct acquisition of technologies, because it enables the firm to diversify risks and costs and complement the knowledge generation it has gained through its R\&D cooperation (van de Vrande et al., 2006).

Second, external R\&D, contrary to our predictions, shows no effects on any types of EI, regardless of how we classify them. This finding confirms prior studies that indicate no significant effect of external R\&D on EI (De Marchi, 2012). This finding also must be understood in relation to the lack of effect of internal R\&D. That is, neither internal nor external R\&D positively contribute to EI. We interpret these results to mean that in most cases, EI are either incremental improvements or radical breakthroughs. From a transaction cost economics perspective (Williamson, 2005), the former might be well suited to the simple acquisition of 
technologies, but the latter requires strong risk governance and coordination through $\mathrm{R} \& \mathrm{D}$ cooperation. In this sense, the contractual relationship associated with external R\&D performed by other organizations then is kind of "stuck in the middle." Finally, internal R\&D was insignificant, which shows how strongly public funding can substitute for private (R\&D) funding (see Guellec and Van Pottelsberghe De La Potterie, 2003; 2004; Maroto et al., 2016).

Third, the acquisition of technology, for both compliance-based and voluntary drivers, occurs mainly in the production stage for internal adoption. The reason for that reflects the combined justifications that we have outlined in the previous paragraphs.

It is also worth mentioning that these results are sensitive to the observation period; they vary notably when we operationalize the independent variables with one versus two windows of observation. This sensitivity probably indicates that the exact drivers and external knowledge search activities of firms differ substantially over time, which makes sense: Environmental regulations and market structures likely change dramatically over a 3-5-year period. Therefore, we suggest that future research should to pay attention to the observation period and specify any major regulatory changes or market turbulence, if they can be controlled for, to ensure the findings are accurate.

The other independent variables also confirm previous results about the positive impacts of knowledge search breadth, absorptive capacity (SIM dominates over internal R\&D, because more than $80 \%$ of firms in the sample are part of a group), public funding, and firm size. Manufacturing firms, especially large ones, take opportunistic advantage of public funding (which in France often goes hand-in-hand with the introduction of more stringent regulations) to develop EI quickly. When firms are part of groups engaged in broad knowledge search, they can identify necessary but missing knowledge. The positive spillover effects derived from belonging to an industrial group and firms' own absorptive capacity development enable firms to develop compliance-based EI rapidly. 
The implications for public policy also are noteworthy. Pinget et al. (2015) suggest that public policies should focus less on financial help, subsidies, or objective measures and more on shaping and modeling firms' perceptions of their environment and the potential benefits of EI. Our study confirms a positive effect of public funding on all types of EI though, including EI linked to regulation and new compulsory measures. Our sample consists mostly of large firms or those that are part of a group, rather than small firms. Further research thus might consider whether firm size can explain these divergent findings. The double externality problem of EI (Rennings, 2000) also prompts policies that help cut the costs of environmentally friendly technological innovations, especially during invention and market introduction phases. Such financial incentives may have immediate effects and encourage firms to search for external technology that can be rapidly assimilated, integrated, and exploited, and then transformed into effective EI.

Finally, our findings are subject to some limitations that should be addressed in further research. In particular, we do not distinguish incremental from radical innovations; incremental innovation is much less demanding, in terms of resources and competencies, than radical innovation. It would be interesting to investigate whether inbound innovation varies according to this dimension of EI. Radical innovations may involve more discontinuity in the sources of innovation, because previously used knowledge sources may grow obsolete in a new context (Laursen and Salter, 2006). Further research also could consider the interaction effects among the different categories of external sources of knowledge and technology on one hand and the different types of EI on the other. Different determinants and outcomes may be interrelated. Such extensions are critical, especially considering the importance of EI for the sustainable growth of both economies and societies. 


\section{Conclusion}

In summary, this article contributes to the increasingly popular research stream pertaining to the drivers that lead firms to adopt EI (e.g., Arora et al., 2014; Hojnik and Ruzzier, 2016; Bossle et al., 2016). It not only specifies the drivers but also formulates a combined typology that reflects firms' inbound innovation strategy. This study provides insights into the contributions of different inbound innovation approaches, in terms of firms' ability to develop and adopt various types of EI, according to a complex combination of drivers. It thus represents an essential step toward a better comprehension of which types of inbound innovation firms use to develop EI, according to their strategy (reactive or proactive) and the locus of innovation (for the firm or for the market). The findings of this article in turn can help firms develop a more precise idea of the respective advantages and effects of using different types of technological sources to create their EI. 


\section{References}

Ambec, S., Cohen, M., Elgie, S., Lanoie, P. 2013. The Porter Hypothesis at 20: Can environmental regulation enhance innovation and competitiveness? Review of Environmental Economics and Policy 7 (1), 2-22.

Arora, S. K., Foley, R. W., Youtie, J., Shapira, P., Wiek, A. 2014. Drivers of technology adoption - the case of nanomaterials in building construction. Technological Forecasting and Social Change 87, 232-244.

Barney, J. 1991. Firm resources and sustained competitive advantage. Journal of Management 17(1), 99-120.

Bocquet, R., Le Bas, C., Mothe, C., Poussing, N. 2013. Are firms with different CSR profiles equally innovative? Empirical analysis with survey data. European Management Journal $31(6), 642-654$.

Bossle, M. B., Dutra De Barcellos, M., Vieira, L. M., Sauvée, L. (2016). The drivers for adoption of eco-innovation. Journal of Cleaner Production 113, 861-872.

Bowman, C., Ambrosini, V. 2000. Value creation versus value capture: Towards a coherent definition of value in strategy. British Journal of Management 11(1), 1-15.

Bönte, W., Dienes, C. 2013. Environmental innovations and strategies for the development of new production technologies: Empirical evidence from Europe. Business Strategy and the Environment 22 (8), 501-516.

Brockhoff, K. 1992. R\&D cooperation between firms-A perceived transaction cost perspective. Management Science 38(4), 514-524.

Buysse, K., Verbeke, A. 2003. Proactive environmental strategies: A stakeholder management perspective. Strategic Management Journal 24(5), 453-470. 
Cainelli, G., Mazzanti, M., Zoboli, R. 2011. Environmental innovations, complementarity and local/global cooperation: evidence from North-East Italian industry. International Journal of Technology, Policy and Management 11(3-4), 328-368.

Cassiman, B., Veugelers, R. 2006. In search of complementarity in innovation strategy: internal R\&D and external knowledge acquisition. Management Science 52(1), 68-82.

Chesbrough, H.W. 2003. Open Innovation: The New Imperative for Creating and Profiting from Technology. Boston, MA: Harvard Business School Press.

Cooper, J. R. (1998). A multidimensional approach to the adoption of innovation. Management decision 36(8), 493-502.

Cyert, R. M., March, J.G. 1963. A behavioral theory of the firm. In Organizational Behavior 2, edited by J. Miner. Englewood Cliffs, NJ: Prentice Hall, pp. 60-78.

Dahlander, L., Gann, D.M., 2010. How open is innovation? Research Policy 39(6), 699-709.

Das, T.K., Teng, B.S. 2000. Instabilities of strategic alliances: An internal tensions perspective. Organization Science 11(1), 77-101.

De Marchi, V. 2012. Environmental innovation and R\&D cooperation: Empirical evidence from Spanish manufacturing firms. Research Policy 41(3), 614-623.

Du, J., Leten, B., Vanhaverbeke, W. 2014. Managing open innovation projects with sciencebased and market-based partners. Research Policy 43(5), 828-840.

Dyer, J.H., Singh, H. 1998. The relational view: Cooperative strategy and sources of interorganizational competitive advantage. Academy of Management Review 23(4), 660679.

Eiadat, Y., Kelly, A., Roche, F., Eyadat, H. 2008. Green and competitive? An empirical test of the mediating role of environmental innovation strategy. Journal of World Business 43(2), $131-145$. 
Enkel, E., Gassmann, O., Chesbrough, H. 2009. Open R\&D and open innovation: exploring the phenomenon. R\&D Management 39(4), 311-316.

Felin, T., Zenger, T.R. 2013. Closed or open innovation? Problem solving and the governance choice. Research Policy 43(5), 914-925.

Frondel, M., Horbach, J., \& Rennings, K. 2008. What triggers environmental management and innovation? Empirical evidence for Germany. Ecological Economics 66(1), 153-160.

Geffen, C. A., Rothenberg, S. 2000. Suppliers and environmental innovation: the automotive paint process. International Journal of Operations \& Production Management 20(2), 166186.

Ghisetti, C., Marzucchi, A., Montresor, S. 2015. The open eco-innovation mode. An empirical investigation of eleven European countries. Research Policy 44(5), 1080-1093.

Gilli, M., Mancinelli, S., Mazzanti, M. (2014). Innovation complementarity and environmental productivity effects: Reality or delusion? Evidence from the EU. Ecological Economics $103,56-67$.

Guellec, D., Van Pottelsberghe De La Potterie, B. 2003. The impact of public R\&D expenditure on business R\&D. Economics of Innovation and New Technology 12, 225-243.

Guellec, D., Van Pottelsberghe De La Potterie, B. 2004. From R\&D to productivity growth: Do the institutional settings and the source of funds of R\&D matter? Oxford Bulletin of Economics and Statistics 66 (3), 353-378.

Gulati, R., Singh, H. 1998. The architecture of cooperation: Managing coordination costs and appropriation concerns in strategic alliances. Administrative Science Quarterly 43(4), $781-814$. 
Hagedoorn, J. 1993. Understanding the rationale of strategic technology partnering: interorganizational modes of co-operation and sectoral differences. Strategic Management Journal 14, 371-385.

Hojnik, J., Ruzzier, M. 2016. What drives eco-innovation? A review of an emerging literature. Environmental Innovation and Societal Transitions 19, 31-41.

Horbach, J. 2008. Determinants of environmental innovation. New evidence from German panel data sources. Research Policy 37(1), 163-173.

Horbach, J., Oltra, V., Belin, J. 2013. Determinants and specificities of eco-innovations. An econometric analysis for the French and German Industry based on the Community Innovation Survey. Industry and Innovation 20 (6), 523-543.

Horbach, J., Rammer, C., Rennings, K. 2012. Determinants of eco-innovations by type of environmental impact - The role of regulatory push/pull, technology push and market pull. Ecological Economics 78, 112-122.

Huizingh, E.K.R.E., 2011. Open innovation: State of the art and future perspectives. Technovation 31(1), 2-9.

Jaffe, A.B., Palmer, K. 1997. Environmental regulation and innovation: A panel data study. Review of Economics and Statistics 79(4), 610-619.

Kammerer, D. 2009. The effects of customer benefit and regulation on environmental product innovation. Empirical evidence from appliance manufacturers in Germany. Ecological Economics 68(8-9), 2285-2295.

Kemp, R., Pearson, P. 2008. Final Report MEI Project about Measuring Eco-Innovation. Maastricht. www.merit.unu.edu/MEI2008.

Kemp, R., Pontoglio, S. 2011. The innovation effects of environmental policy instruments - A typical case of the blind men and the elephant? Ecological Economics 72, 28-36. 
Kesidou, E., Demirel, P. 2012. On the drivers of eco-innovations: Empirical evidence from the UK. Research Policy 41(5), 862-870.

Laursen, K., A. Salter, A. 2006. Open for innovation: The role of openness in explaining innovation performance among U.K. manufacturing firms. Strategic Management Journal 27(2), 131-50.

Laursen, K., Salter, A. 2014. The paradox of openness: Appropriability, external search and collaboration. Research Policy 43(5), 867-878.

Lepak, D.P., Smith, K.G., Taylor, M.S. 2007. Value creation and value capture: a multilevel perspective. Academy of Management Review 32(1), 180-194.

Li, Y., Vanhaverbeke, W. 2009. The Effects of inter-industry and country difference in supplier relationships on pioneering innovations. Technovation $29,843-858$

Li-Ying, J., Wang, Y. 2015. Find them home or abroad? The relative contribution of international technology in-licensing to the 'indigenous innovation' in China. Long Range Planning 48(3), 123-134.

Li-Ying, J., Wang, Y., Salomo, S., Vanhaverbeke, W. 2013. Have Chinese firms learnt from their prior technology in-licensing? An analysis based on patent citations. Scientometrics 95(1), 183-195.

Li-Ying, J. 2016. Dual boundary spanning — towards a typology of outside-in open innovation reflected by the Canadian context. Canadian Journal of Administrative Sciences Online early view, DOI: $10.1002 /$ cjas. 1428 .

Marin, G., Lotti, F. 2017. Productivity effects of eco-innovations using data on eco-patents. Industrial and Corporate Change 26(1), 125-148.

Maroto, A., Gallego, J., Rubalcaba, L. 2016. Publicly funded R\&D for public sector performance and efficiency: evidence from Europe. $R \& D$ Management 46(S2), 564-578. 
NBC News, World Environment, 2005. Europe bans chemicals used in toys. http://www.nbcnews.com/id/8473765/ns/world_news-environment/t/europe-banschemical-used-toys/\#.WQrgh-Swc2w. Accessed on May 4 ${ }^{\text {th }}, 2017$.

Nieto, M. J., Santamaría, L. 2010. Technological collaboration: Bridging the innovation gap between small and large firms. Journal of Small Business Management 48(1), 44-69.

Parker, C. 2000. Reinventing regulation within the corporation: Compliance-oriented regulatory innovation. Administration \& Society 32(5), 529-565.

Pinget, A., Bocquet, R., Mothe, C. 2015. Barriers to environmental innovation in SMEs: Empirical evidence from French firms.M@n@gement 18(2), 132-155.

Porter, M.E., van der Linde, C. 1995. Toward a new conception of the environmentcompetitiveness relationship. Journal of Economic Perspectives 9, 97-118.

Porter, M., van der Linde, C. 1996. Green and competitive: Ending the stalemate. In R. Welford \& R. Starkey (Eds.), The Earthscan Reader in Business and the Environment. London: Earthscan, pp. 61-77.

Rennings, K. 2000. Redefining innovation: Eco-innovation research and the contribution from ecological economics. Ecological Economics, 32(2), 319-332.

Rennings, K., Rammer, C. 2009. Increasing energy and resource efficiency through innovation - an explorative analysis using innovation survey data. Czech Journal of Economics and Finance 59 (1), 442-459.

Rexhäuser, S., Rammer, C. 2014. Environmental innovations and firm profitability: Unmasking the Porter Hypothesis. Environmental and Resource Economics 57(1), 145-167.

Robertson, T. S., Gatignon, H. 1998. Technology development mode: A transaction cost conceptualization. Strategic Management Journal 19(6), 515-531. 
Sharma, S., Vredenburg, H. 1998. Proactive corporate environmental strategy and the development of competitively valuable organizational capabilities. Strategic Management Journal 19(8), 729-753.

StataCorp. 2009. Stata Statistical Software: Release 11. College Station, TX: StataCorp LP.

Teece, D.J. 2007. Explicating dynamic capabilities: The nature and microfoundations of (sustainable) enterprise performance. Strategic Management Journal 28(13), 1319-1350.

Teece, D.J. 2014. The foundations of enterprise performance: Dynamic and ordinary capabilities in an (economic) theory of firms. Academy of Management Perspectives 28(4), $328-352$.

Triguero, A., Moreno-Mondéjar, L., Davia, M. A. 2013. Drivers of different types of ecoinnovation in European SMEs. Ecological Economics 92, 25-33.

van de Vrande, V., Lemmens, C., Vanhaverbeke, W. 2006. Choosing governance modes for external technology sourcing. R\&D Management 36(3), 347-363.

Wang, Y., Li-Ying, J. 2015. Licensing foreign technology and the moderating role of local R\&D collaboration: Extending the relational view. Journal of Product Innovation Management 32(6), 997-1013.

Wagner, M. 2008. Empirical influence of environmental management on innovation: Evidence from Europe. Ecological Economics 66(2-3), 392-402.

West, J., Bogers, M. 2014. Leveraging external sources of innovation: A review of research on open innovation. Journal of Product Innovation Management 31(4), 814-831.

Williamson, O. E. 2005. The economics of governance. American Economic Review 1-18. 
Figure 1: Driver-based typology of environmental innovations

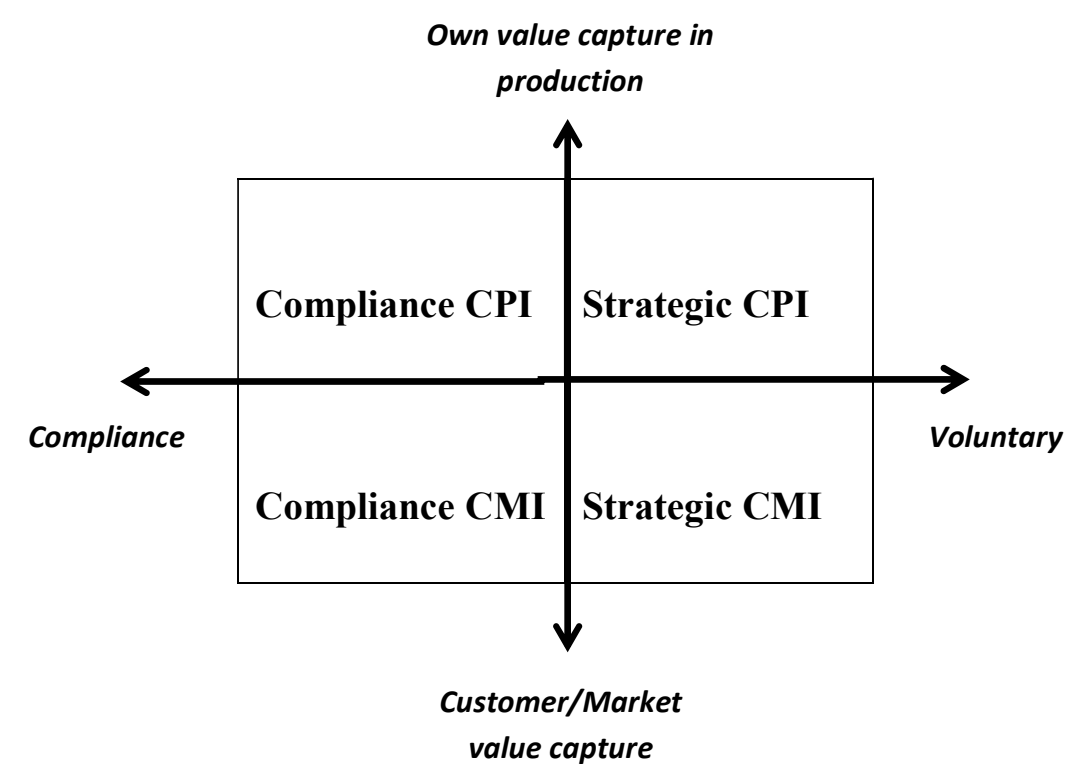

Notes: These four types are not mutually exclusive for a particular firm to deploy. 
Table 1: Correlations

\begin{tabular}{|c|c|c|c|c|c|c|c|c|c|c|c|c|c|c|c|c|c|}
\hline & $(1)$ & (2) & (3) & (4) & $(5)$ & (6) & (7) & $(8)$ & (9) & $(10)$ & (11) & $(12)$ & $(13)$ & (14) & $(15)$ & (16) & $(17)$ \\
\hline Compliance CPI (1) & 1 & & & & & & & & & & & & & & & & \\
\hline Strategic CPI (2) & $0.65^{*}$ & 1 & & & & & & & & & & & & & & & \\
\hline Compliance CMI (3) & $0.50^{*}$ & $0.65^{*}$ & 1 & & & & & & & & & & & & & & \\
\hline Strategic CMI (4) & $0.75^{*}$ & $0.50^{*}$ & $0.76^{*}$ & 1 & & & & & & & & & & & & & \\
\hline Acquisition of tech (5) & $0.31^{*}$ & $0.37^{*}$ & $0.28^{*}$ & $0.23 *$ & 1 & & & & & & & & & & & & \\
\hline External R\&D (6) & $0.29^{*}$ & $0.33^{*}$ & $0.28^{*}$ & $0.26^{*}$ & $0.32 *$ & 1 & & & & & & & & & & & \\
\hline R\&D cooperation (7) & $0.37^{*}$ & $0.40^{*}$ & $0.31^{*}$ & $0.30^{*}$ & $0.34 *$ & $0.46^{*}$ & 1 & & & & & & & & & & \\
\hline Breadth (8) & $0.45^{*}$ & $0.51^{*}$ & $0.41^{*}$ & $0.39 *$ & $0.44^{*}$ & $0.46^{*}$ & $0.52 *$ & 1 & & & & & & & & & \\
\hline Breadth_sq (9) & $0.42^{*}$ & $0.48^{*}$ & $0.39^{*}$ & $0.38^{*}$ & $0.39^{*}$ & $0.44 *$ & $0.50^{*}$ & $0.97^{*}$ & 1 & & & & & & & & \\
\hline Internal R\&D (10) & $0.34 *$ & $0.41^{*}$ & $0.35^{*}$ & $0.30^{*}$ & $0.37^{*}$ & $0.40^{*}$ & $0.49^{*}$ & $0.72 *$ & $0.64 *$ & 1 & & & & & & & \\
\hline SIM (11) & $0.32^{*}$ & $0.40^{*}$ & $0.33^{*}$ & $0.28^{*}$ & $0.39^{*}$ & $0.33^{*}$ & $0.35^{*}$ & $0.49^{*}$ & $0.43^{*}$ & $0.51^{*}$ & 1 & & & & & & \\
\hline Public funding (12) & $0.30^{*}$ & $0.24 *$ & $0.22^{*}$ & $0.30^{*}$ & $0.14^{*}$ & $0.10^{*}$ & $0.14 *$ & $0.19^{*}$ & $0.19^{*}$ & $0.12^{*}$ & $0.13^{*}$ & 1 & & & & & \\
\hline Belonging to group (13) & $0.22 *$ & $0.31^{*}$ & $0.25^{*}$ & $0.19^{*}$ & $0.14^{*}$ & $0.23^{*}$ & $0.24 *$ & $0.28 *$ & $0.27^{*}$ & $0.24 *$ & $0.21^{*}$ & $0.09^{*}$ & 1 & & & & \\
\hline Size (14) & $0.36^{*}$ & $0.42^{*}$ & $0.36^{*}$ & $0.32 *$ & $0.22 *$ & $0.32^{*}$ & $0.36^{*}$ & $0.41^{*}$ & $0.40^{*}$ & $0.33^{*}$ & $0.35^{*}$ & $0.20^{*}$ & $0.52^{*}$ & 1 & & & \\
\hline Market geography (15) & $0.31^{*}$ & $0.37^{*}$ & $0.31^{*}$ & $0.26^{*}$ & $0.26^{*}$ & $0.29^{*}$ & $0.35^{*}$ & $0.67^{*}$ & $0.63^{*}$ & $0.55^{*}$ & $0.37^{*}$ & $0.13 *$ & $0.16^{*}$ & $0.25^{*}$ & 1 & & \\
\hline High tech (16) & 0.01 & -0.03 & -0.03 & -0.02 & $0.07^{*}$ & $0.11^{*}$ & $0.10^{*}$ & $0.08^{*}$ & $0.08^{*}$ & $0.06^{*}$ & $0.08^{*}$ & 0.01 & 0.02 & $0.09^{*}$ & 0.01 & 1 & \\
\hline Med-high tech (17) & $0.08 *$ & $0.14 *$ & $0.14 *$ & $0.11 *$ & 0.01 & $0.07 *$ & 0.05 & $0.11 *$ & $0.09 *$ & $0.11^{*}$ & $0.07 *$ & 0.01 & $0.08 *$ & 0.04 & $0.14 *$ & $-0.40^{*}$ & 1 \\
\hline
\end{tabular}


Table 2: Bivariate Probit regressions results for inbound innovation, 2006-2008

\begin{tabular}{|c|c|c|c|c|c|c|}
\hline & \multicolumn{2}{|l|}{ All EI } & \multicolumn{2}{|c|}{$\begin{array}{l}\begin{array}{l}\text { Production stage (own } \\
\text { adoption) }\end{array} \\
\end{array}$} & \multicolumn{2}{|c|}{ Final use stage (market adoption) } \\
\hline & Compliance & Voluntary & Compliance & Voluntary & Compliance & Voluntary \\
\hline & & & Compliance CPI & Strategic CPI & Compliance CMI & Strategic $C M I$ \\
\hline \multicolumn{7}{|l|}{ Main effect variables } \\
\hline$R \& D$ cooperation & $\begin{array}{c}0.405 * * * \\
(0.103)\end{array}$ & $\begin{array}{c}0.368^{* * *} \\
(0.118)\end{array}$ & $\begin{array}{c}0.375 * * * \\
(0.103)\end{array}$ & $\begin{array}{c}0.353 * * * \\
(0.115)\end{array}$ & $\begin{array}{l}0.179 * \\
(0.104)\end{array}$ & $\begin{array}{c}0.233^{* *} \\
(0.104)\end{array}$ \\
\hline External R\&D & $\begin{array}{c}0.066 \\
(0.102)\end{array}$ & $\begin{array}{c}0.157 \\
(0.114)\end{array}$ & $\begin{array}{c}0.077 \\
(0.102)\end{array}$ & $\begin{array}{c}0.155 \\
(0.111)\end{array}$ & $\begin{array}{c}0.145 \\
(0.101)\end{array}$ & $\begin{array}{c}0.110 \\
(0.099)\end{array}$ \\
\hline Acquisition of tech. & $\begin{array}{c}0.240 * * \\
(0.099)\end{array}$ & $\begin{array}{c}0.363 * * * \\
(0.110)\end{array}$ & $\begin{array}{c}0.261 * * * \\
(0.098)\end{array}$ & $\begin{array}{c}0.410 * * * \\
(0.106)\end{array}$ & $\begin{array}{c}0.200 * * \\
(0.099)\end{array}$ & $\begin{array}{c}0.105 \\
(0.098)\end{array}$ \\
\hline \multicolumn{7}{|l|}{ Control variables } \\
\hline Breadth & $\begin{array}{c}0.192 * * * \\
(0.064)\end{array}$ & $\begin{array}{c}0.188 * * * \\
(0.070)\end{array}$ & $\begin{array}{c}0.172 * * * \\
(0.065)\end{array}$ & $\begin{array}{c}0.150 * * \\
(0.069)\end{array}$ & $\begin{array}{l}0.112 * \\
(0.065)\end{array}$ & $\begin{array}{c}0.157 * * \\
(0.064)\end{array}$ \\
\hline Breadth_sq & $\begin{array}{l}-0.009 * \\
(0.006)\end{array}$ & $\begin{array}{l}-0.010 \\
(0.006)\end{array}$ & $\begin{array}{l}-0.008 \\
(0.006)\end{array}$ & $\begin{array}{l}-0.007 \\
(0.006)\end{array}$ & $\begin{array}{l}-0.005 \\
(0.006)\end{array}$ & $\begin{array}{l}-0.007 \\
(0.006)\end{array}$ \\
\hline Internal R\&D & $\begin{array}{l}-0.119 \\
(0.150)\end{array}$ & $\begin{array}{l}-0.158 \\
(0.160)\end{array}$ & $\begin{array}{l}-0.0726 \\
(0.152)\end{array}$ & $\begin{array}{l}-0.145 \\
(0.164)\end{array}$ & $\begin{array}{c}0.122 \\
(0.154)\end{array}$ & $\begin{array}{l}0.0556 \\
(0.148)\end{array}$ \\
\hline SIM & $\begin{array}{c}0.224^{* *} \\
(0.104)\end{array}$ & $\begin{array}{c}0.370^{* * *} \\
(0.111)\end{array}$ & $\begin{array}{l}0.201 * \\
(0.103)\end{array}$ & $\begin{array}{c}0.352 * * * \\
(0.109)\end{array}$ & $\begin{array}{c}0.280 * * * \\
(0.104)\end{array}$ & $\begin{array}{l}0.196^{*} \\
(0.104)\end{array}$ \\
\hline Public funding & $\begin{array}{c}1.259^{* * *} \\
(0.198)\end{array}$ & $\begin{array}{c}6.415^{* * *} \\
(0.253)\end{array}$ & $\begin{array}{c}1.227 * * * \\
(0.191)\end{array}$ & $\begin{array}{c}2.149 * * * \\
(0.443)\end{array}$ & $\begin{array}{c}0.761 * * * \\
(0.161)\end{array}$ & $\begin{array}{c}0.941 * * * \\
(0.155)\end{array}$ \\
\hline Belonging to group & $\begin{array}{l}0.0376 \\
(0.151)\end{array}$ & $\begin{array}{c}0.348^{* *} \\
(0.155)\end{array}$ & $\begin{array}{l}0.0309 \\
(0.151)\end{array}$ & $\begin{array}{l}0.289^{*} \\
(0.152)\end{array}$ & $\begin{array}{l}0.269 * \\
(0.151)\end{array}$ & $\begin{array}{l}0.0407 \\
(0.158)\end{array}$ \\
\hline Size & $\begin{array}{c}0.204 * * * \\
(0.049)\end{array}$ & $\begin{array}{c}0.237 * * * \\
(0.055)\end{array}$ & $\begin{array}{c}0.212^{* * *} \\
(0.048)\end{array}$ & $\begin{array}{c}0.244 * * * \\
(0.053)\end{array}$ & $\begin{array}{c}0.198 * * * \\
(0.050)\end{array}$ & $\begin{array}{c}0.181 * * * \\
(0.050)\end{array}$ \\
\hline Market geography & $\begin{array}{c}0.034 \\
(0.070)\end{array}$ & $\begin{array}{l}0.138 * \\
(0.078)\end{array}$ & $\begin{array}{c}0.037 \\
(0.069)\end{array}$ & $\begin{array}{c}0.117 \\
(0.075)\end{array}$ & $\begin{array}{c}0.085 \\
(0.068)\end{array}$ & $\begin{array}{l}-0.012 \\
(0.068)\end{array}$ \\
\hline High & $\begin{array}{l}-0.199 \\
(0.129)\end{array}$ & $\begin{array}{c}-0.438^{* * *} \\
(0.142)\end{array}$ & $\begin{array}{l}-0.141 \\
(0.128)\end{array}$ & $\begin{array}{c}-0.371^{* * *} \\
(0.138)\end{array}$ & $\begin{array}{c}-0.262 * * \\
(0.133)\end{array}$ & $\begin{array}{l}-0.240 * \\
(0.129)\end{array}$ \\
\hline Med-high & $\begin{array}{c}0.019 \\
(0.102)\end{array}$ & $\begin{array}{c}0.114 \\
(0.107)\end{array}$ & $\begin{array}{c}0.061 \\
(0.101)\end{array}$ & $\begin{array}{c}0.138 \\
(0.105)\end{array}$ & $\begin{array}{c}0.158 \\
(0.098)\end{array}$ & $\begin{array}{c}0.159 \\
(0.102)\end{array}$ \\
\hline Constant & $\begin{array}{c}-2.437 * * * \\
(0.258)\end{array}$ & $\begin{array}{c}-2.577 * * * \\
(0.281)\end{array}$ & $\begin{array}{c}-2.498 * * * \\
(0.258)\end{array}$ & $\begin{array}{c}-2.597 * * * \\
(0.273)\end{array}$ & $\begin{array}{c}-2.654 * * * \\
(0.265)\end{array}$ & $\begin{array}{c}-2.605^{* * *} \\
(0.272)\end{array}$ \\
\hline Observations & 1,023 & & 1,023 & & 1,023 & \\
\hline Log Likelihood & -801.00 & & -921.00 & & -787.00 & \\
\hline$p$-Value & 0.00 & & 0.00 & & 0.00 & \\
\hline Rho & $0.854(0.54)$ & & $0.752(0.62)$ & & $0.875(0.42)$ & \\
\hline Wald $\chi^{2}$ & 141.24 & & 138.04 & & 154.25 & \\
\hline
\end{tabular}

Notes: Standard errors are in parentheses.

$* * * p<.01, * * p<.05, * p<.1$. 


\section{Appendix 1: Variable definitions}

\begin{tabular}{|c|c|}
\hline Variables & Description \\
\hline \multicolumn{2}{|c|}{ Dependent Variables } \\
\hline Compliance EI & $\begin{array}{l}\text { Equal to } 1 \text { if the firm has introduced a new or significantly improved product or process innovation with } \\
\text { environmental benefits and in response to at least one of the following regulations: (1) existing environmental } \\
\text { regulations; (2) expected environmental innovation; (3) control procedures for regularly identifying and } \\
\text { reducing environmental impacts (ISO } 14001 \text { certifications, environmental audits), } 0 \text { otherwise }\end{array}$ \\
\hline Voluntary EI & $\begin{array}{l}\text { Equal to } 1 \text { if the firm has introduced a new or significantly improved product or process innovation with } \\
\text { environmental benefits and in response to at least one of the following motivations: (1) response to the current } \\
\text { and expected market demand; (2) beneficing from grants, subsidies or other financial incentives; (3) voluntary } \\
\text { codes or agreements for environmental good practices within the sector, } 0 \text { otherwise }\end{array}$ \\
\hline Compliance CPI & $\begin{array}{l}\text { Equal to } 1 \text { if the firm has introduced a new or significantly improved product or process innovation with } \\
\text { environmental benefits at the production stage ((1) reduced material use per unit of output; }(2) \text { reduced energy } \\
\text { use per unit of output; }(3) \text { reduced } \mathrm{CO}_{2} \text { footprint (total } \mathrm{CO}_{2} \text { production) by the enterprise; (4) replaced } \\
\text { materials with less polluting or hazardous substitutes; (5) reduced soil, water, noise, or air pollution; and (6) } \\
\text { recycled waste, water, or materials) and in response to "Compliance" motivations; } 0 \text { otherwise }\end{array}$ \\
\hline Compliance CMI & $\begin{array}{l}\text { Equal to } 1 \text { if the firm has introduced a new or significantly improved product or process innovation with } \\
\text { environmental benefits at the final use stage ((1) reduced energy use, (2) reduced air, water, soil or noise } \\
\text { pollution; and (3) improved recycling of product after use) and in response to "Compliance" motivations; } 0 \\
\text { otherwise }\end{array}$ \\
\hline Strategic CPI & $\begin{array}{l}\text { Equal to } 1 \text { if the firm has introduced a new or significantly improved product or process innovation with } \\
\text { environmental benefits at the production stage ((1) reduced material use per unit of output; }(2) \text { reduced energy } \\
\text { use per unit of output; }(3) \text { reduced } \mathrm{CO}_{2} \text { footprint (total } \mathrm{CO}_{2} \text { production) by the enterprise; (4) replaced } \\
\text { materials with less polluting or hazardous substitutes; (5) reduced soil, water, noise, or air pollution; and (6) } \\
\text { recycled waste, water, or materials) and in response to "Voluntary" motivations; } 0 \text { otherwise }\end{array}$ \\
\hline Strategic CMI & $\begin{array}{l}\text { Equal to } 1 \text { if the firm has introduced a new or significantly improved product or process innovation with } \\
\text { environmental benefits at the final use stage ((1) reduced energy use, (2) reduced air, water, soil or noise } \\
\text { pollution; and (3) improved recycling of product after use) and in response to "Voluntary" motivations; } 0 \\
\text { otherwise }\end{array}$ \\
\hline Dual EI & $\begin{array}{l}\text { Equal to } 1 \text { if the firm has introduced a new or significantly improved product or process innovation with } \\
\text { environmental benefits in response to "Voluntary" AND "Compliance" motivations; } 0 \text { otherwise }\end{array}$ \\
\hline
\end{tabular}

Only_strategic EI Equal to 1 if the firm has introduced a new or significantly improved product or process innovation with environmental benefits in response to ONLY "Voluntary" motivations; 0 otherwise

Dual CPI Equal to 1 if the firm has introduced a new or significantly improved product or process innovation with environmental benefits at the production and in response to "Compliance" AND "Voluntary" motivations; 0 otherwise

Only_strategic CPI Equal to 1 if the firm has introduced a new or significantly improved product or process innovation with environmental benefits at the production and in response to only "Voluntary" motivations; 0 otherwise

Dual CMI Equal to 1 if the firm has introduced a new or significantly improved product or process innovation with environmental benefits at the final use stage and in response to "Voluntary" AND "Compliance" motivations; 0 otherwise

Only_strategic CMI Equal to 1 if the firm has introduced a new or significantly improved product or process innovation with environmental benefits at the final use stage and in response to only "Voluntary" motivations; 0 otherwise

\section{Independent and Control Variables}

Acquisition of external technologies

External R\&D

R\&D Cooperation

Internal R\&D

Breadth

SIM

Public funding

Belonging to group

Size

High technology

Medium high technology
Equal to 1 if the firm purchase or licensing of patents and non-patented inventions, know-how, and other types of knowledge from other enterprises or organizations for the development of new or significantly improved products and processes during 2006-2008, 0 otherwise

Equal to 1 if the firm's R\&D activities are performed by other firms or public or private research organizations and purchased by the firm, 0 otherwise

Equal to 1 if the firm undertakes R\&D cooperation for innovation activities with other firms or institutions during 2006-2008 (excluding R\&D activities conducted entirely for the public sector under contract), 0 otherwise

Equal to 1 if the firm undertakes R\&D activities within the firm to increase the stock of knowledge

Sum of three information sources: market sourcing, institutional sourcing, other sourcing, 0 if none

Equal to 1 if departments within the firm or enterprises within the same group as sources of information are "crucial" for the firm's innovation process, 0 otherwise

Equal to 1 if the firm has received any public financial support for innovation activities during the period 2006-2008, 0 otherwise

Equal to 1 if part of a group; 0 otherwise

Logarithm of the number of employees

High-tech manufacturing

Medium high-tech manufacturing 
Appendix 2: Descriptive statistics for environmental innovation in $\mathrm{t}(\%)$.

\begin{tabular}{llllll}
\hline \hline & Obs & Mean & Std.Dev & Min & Max \\
\hline Compliance EI & 1023 & .46 & .49 & 0 & 1 \\
Strategic EI & 1023 & .58 & .48 & 0 & 1 \\
Compliance CPI & 1023 & .45 & .49 & 0 & 1 \\
Strategic CPI & 1023 & .56 & .50 & 0 & 1 \\
Compliance CMI & 1023 & .41 & .49 & 0 & 1 \\
Strategic CMI & 1023 & .33 & .47 & 0 & 1 \\
Dual EI & 1023 & .38 & .48 & 0 & 1 \\
Only_strategic EI & 1023 & .21 & .41 & 0 & 1 \\
Dual CPI & 1023 & .37 & .48 & 0 & 1 \\
Only-strategic CPI & 1023 & .14 & .35 & 0 & 1 \\
Dual CMI & 1023 & .28 & .48 & 0 & 1 \\
Only-strategic CMI & 1023 & .08 & .27 & 0 & 17 \\
\hline \hline
\end{tabular}

Appendix 3: Descriptive statistics for explanatory variables (\%).

\begin{tabular}{|c|c|c|c|c|c|c|c|c|c|}
\hline & \multirow[b]{2}{*}{ Obs } & \multicolumn{4}{|l|}{ CIS08 } & \multicolumn{4}{|l|}{ CIS06 } \\
\hline & & Mean & Std.Dev. & Min & Max & Mean & Std.Dev. & Min & $\operatorname{Max}$ \\
\hline Acquisition of tech & 1023 & .46 & .49 & 0 & 1 & .57 & .49 & 0 & 1 \\
\hline External R\&D & 1023 & .38 & .48 & 0 & 1 & .37 & .48 & 0 & 1 \\
\hline R\&D cooperation & 1023 & .45 & .49 & 0 & 1 & .39 & .48 & 0 & 1 \\
\hline Breadth & 1023 & 5.07 & 3.65 & 0 & 9 & 4.25 & 3.68 & 0 & 9 \\
\hline Internal R\&D & 1023 & .68 & .46 & 0 & 1 & .61 & .48 & 0 & 1 \\
\hline SIM & 1023 & .55 & .49 & 0 & 1 & .45 & .49 & 0 & 1 \\
\hline Public funding & 1023 & .10 & .3 & 0 & 1 & & & & \\
\hline Belonging to group & 1023 & .82 & .37 & 0 & 1 & & & & \\
\hline Size & 1023 & 5.74 & 1.23 & 2.83 & 9.91 & & & & \\
\hline Market geography & 1023 & .87 & .84 & 0 & 2 & & & & \\
\hline High tech & 1023 & .18 & .38 & 0 & 1 & & & & \\
\hline Med-high tech & 1023 & .41 & .49 & 0 & 1 & & & & \\
\hline
\end{tabular}

\footnotetext{
${ }^{7}$ As there is only $3.6 \%$ of firms in our sample (37 observations) which have introduced environmental innovation in response exclusively to regulations (only compliance), we decide not to run estimation for this sub-sample.
} 
Appendix 4: Bivariate Probit regressions results for inbound innovation, independent variables from CIS6 (2004-2006) and dependent variables from CIS8 (2006-2008)

\begin{tabular}{|c|c|c|c|c|c|c|}
\hline & \multicolumn{2}{|l|}{ All EI } & \multirow{2}{*}{$\begin{array}{l}\begin{array}{l}\text { Production } \\
\text { adoption) }\end{array} \\
\text { Compliance }\end{array}$} & \multirow{2}{*}{$\begin{array}{l}\text { stage (own } \\
\text { Voluntary }\end{array}$} & \multirow{2}{*}{$\begin{array}{l}\text { Use stage } \\
\text { adoption) } \\
\text { Compliance }\end{array}$} & \multirow{2}{*}{$\begin{array}{r}\text { (market } \\
\text { - Voluntary }\end{array}$} \\
\hline & Compliance & Voluntary & & & & \\
\hline & & & $\begin{array}{l}\text { Compliance } \\
\text { CPI }\end{array}$ & $\begin{array}{l}\text { Strategic } \\
C P I\end{array}$ & $\begin{array}{l}\text { Compliance } \\
\text { CMI }\end{array}$ & $\begin{array}{l}\text { Strategic } \\
C M I\end{array}$ \\
\hline \multicolumn{7}{|l|}{ Main effect variables } \\
\hline $\mathrm{R} \& \mathrm{D}$ cooperation & $\begin{array}{l}0.265^{* *} \\
(0.109)\end{array}$ & $\begin{array}{l}0.290 * * * \\
(0.110)\end{array}$ & $\begin{array}{l}0.256^{* *} \\
(0.109)\end{array}$ & $\begin{array}{l}0.233 * * \\
(0.110)\end{array}$ & $\begin{array}{l}0.142 \\
(0.108)\end{array}$ & $\begin{array}{l}0.068 \\
(0.109)\end{array}$ \\
\hline External R\&D & $\begin{array}{l}-0.077 \\
(0.111)\end{array}$ & $\begin{array}{l}-0.106 \\
(0.111)\end{array}$ & $\begin{array}{l}-0.042 \\
(0.111)\end{array}$ & $\begin{array}{l}-0.016 \\
(0.110)\end{array}$ & $\begin{array}{l}-0.064 \\
(0.108)\end{array}$ & $\begin{array}{l}-0.004 \\
(0.108)\end{array}$ \\
\hline Acquisition of tech. & $\begin{array}{l}0.094 \\
(0.119)\end{array}$ & $\begin{array}{l}-0.002 \\
(0.118)\end{array}$ & $\begin{array}{l}0.089 \\
(0.120)\end{array}$ & $\begin{array}{l}-0.000 \\
(0.118)\end{array}$ & $\begin{array}{l}-0.163 \\
(0.115)\end{array}$ & $\begin{array}{l}-0.023 \\
(0.120)\end{array}$ \\
\hline \multicolumn{7}{|l|}{ Control variables } \\
\hline Breadth & $\begin{array}{l}0.241 * * * \\
(0.063)\end{array}$ & $\begin{array}{l}0.247 * * * \\
(0.066)\end{array}$ & $\begin{array}{l}0.223 * * * \\
(0.063)\end{array}$ & $\begin{array}{l}0.216 * * * \\
(0.065)\end{array}$ & $\begin{array}{l}0.157 * * \\
(0.063)\end{array}$ & $\begin{array}{l}0.179 * * * \\
(0.063)\end{array}$ \\
\hline Breadth_sq & $\begin{array}{l}-0.013^{* *} \\
(0.006)\end{array}$ & $\begin{array}{l}-0.014^{* *} \\
(0.006)\end{array}$ & $\begin{array}{l}-0.012 * * \\
(0.006)\end{array}$ & $\begin{array}{l}-0.011^{*} \\
(0.006)\end{array}$ & $\begin{array}{l}-0.007 \\
(0.006)\end{array}$ & $\begin{array}{l}-0.007 \\
(0.006)\end{array}$ \\
\hline Internal R\&D & $\begin{array}{l}-0.045 \\
(0.147)\end{array}$ & $\begin{array}{l}-0.013 \\
(0.159)\end{array}$ & $\begin{array}{l}-0.0060 \\
(0.148)\end{array}$ & $\begin{array}{l}-0.033 \\
(0.160)\end{array}$ & $\begin{array}{l}0.191 \\
(0.153)\end{array}$ & $\begin{array}{l}0.130 \\
(0.145)\end{array}$ \\
\hline SIM & $\begin{array}{l}0.255 * * \\
(0.103)\end{array}$ & $\begin{array}{l}0.429 * * * \\
(0.107)\end{array}$ & $\begin{array}{l}0.238 * * \\
(0.103)\end{array}$ & $\begin{array}{l}0.424 * * * \\
(0.107)\end{array}$ & $\begin{array}{l}0.360 * * * \\
(0.104)\end{array}$ & $\begin{array}{l}0.229 * * \\
(0.104)\end{array}$ \\
\hline Public funding & $\begin{array}{l}1.256^{* * *} \\
(0.195)\end{array}$ & $\begin{array}{l}0.947 * * * \\
(0.193)\end{array}$ & $\begin{array}{l}1.227^{* * *} \\
(0.189)\end{array}$ & $\begin{array}{l}0.954 * * * \\
(0.183)\end{array}$ & $\begin{array}{l}0.633 * * * \\
(0.146)\end{array}$ & $\begin{array}{l}0.965 * * * \\
(0.155)\end{array}$ \\
\hline Belonging to group & $\begin{array}{l}0.033 \\
(0.147)\end{array}$ & $\begin{array}{l}0.363 * * \\
(0.152)\end{array}$ & $\begin{array}{l}0.028 \\
(0.147)\end{array}$ & $\begin{array}{l}0.299 * * \\
(0.150)\end{array}$ & $\begin{array}{l}0.321 * * \\
(0.153)\end{array}$ & $\begin{array}{l}0.068 \\
(0.152)\end{array}$ \\
\hline Size & $\begin{array}{l}0.215^{* * *} \\
(0.049)\end{array}$ & $\begin{array}{l}0.273 * * * \\
(0.054)\end{array}$ & $\begin{array}{l}0.220^{* * *} \\
(0.048)\end{array}$ & $\begin{array}{l}0.276^{* * *} \\
(0.053)\end{array}$ & $\begin{array}{l}0.236^{* * *} \\
(0.050)\end{array}$ & $\begin{array}{l}0.196 * * * \\
(0.050)\end{array}$ \\
\hline Market geography & $\begin{array}{l}0.011 \\
(0.069)\end{array}$ & $\begin{array}{l}0.097 \\
(0.074)\end{array}$ & $\begin{array}{l}0.014 \\
(0.068)\end{array}$ & $\begin{array}{l}0.084 \\
(0.072)\end{array}$ & $\begin{array}{l}0.068 \\
(0.068)\end{array}$ & $\begin{array}{l}-0.024 \\
(0.067)\end{array}$ \\
\hline High tech & $\begin{array}{l}-0.180 \\
(0.127)\end{array}$ & $\begin{array}{l}-0.400^{* * *} \\
(0.136)\end{array}$ & $\begin{array}{l}-0.124 \\
(0.126)\end{array}$ & $\begin{array}{l}-0.355^{* * *} \\
(0.134)\end{array}$ & $\begin{array}{l}-0.231 * \\
(0.132)\end{array}$ & $\begin{array}{l}-0.208 \\
(0.129)\end{array}$ \\
\hline Med-high tech & $\begin{array}{l}0.003 \\
(0.101)\end{array}$ & $\begin{array}{l}0.103 \\
(0.105)\end{array}$ & $\begin{array}{l}0.042 \\
(0.101)\end{array}$ & $\begin{array}{l}0.110 \\
(0.103)\end{array}$ & $\begin{array}{l}0.174 * \\
(0.098)\end{array}$ & $\begin{array}{l}0.164 \\
(0.101)\end{array}$ \\
\hline Constant & $\begin{array}{l}-2.509 * * * \\
(0.258)\end{array}$ & $\begin{array}{l}-2.765^{* * *} \\
(0.282)\end{array}$ & $\begin{array}{l}-2.551 * * * \\
(0.258)\end{array}$ & $\begin{array}{l}-2.747 * * * \\
(0.276)\end{array}$ & $\begin{array}{l}-2.849 * * * \\
(0.269)\end{array}$ & $\begin{array}{l}-2.681 * * * \\
(0.269)\end{array}$ \\
\hline Observations & 1,023 & & 1,023 & & 1,023 & \\
\hline Log Likelihood & -854.00 & & -808.00 & & -875.00 & \\
\hline$p$-Value & 0.00 & & 0.00 & & 0.00 & \\
\hline Rho & $0.795(0.561)$ & & $0.875(0.588)$ & & $0.790(0.500)$ & \\
\hline Wald $\chi^{2}$ & 122.45 & & 131.00 & & 141.35 & \\
\hline
\end{tabular}

Notes: Standard errors are in parentheses.

$* * * p<.01, * * p<.05, * p<.1$. 
Appendix 5: Bivariate Probit regressions results for inbound innovation, independent variables from CIS 6 (2004-2006) and CIS8 (2006-2008) combined and dependent variables from CIS8

\begin{tabular}{|c|c|c|c|c|c|c|}
\hline & \multicolumn{2}{|l|}{ All EI } & \multirow{2}{*}{$\begin{array}{l}\text { Production } \\
\text { adoption) } \\
\text { Compliance }\end{array}$} & \multirow{2}{*}{$\begin{array}{l}\text { stage (own } \\
\text { Voluntary }\end{array}$} & \multirow{2}{*}{$\begin{array}{l}\begin{array}{l}\text { Use stage } \\
\text { adoption) }\end{array} \\
\text { Compliance }\end{array}$} & \multirow{2}{*}{$\begin{array}{r}\text { (market } \\
\text { Voluntary }\end{array}$} \\
\hline & Compliance & Voluntary & & & & \\
\hline & & & $\begin{array}{l}\text { Compliance } \\
\text { CPI }\end{array}$ & $\begin{array}{l}\text { Strategic } \\
\text { CPI }\end{array}$ & $\begin{array}{l}\text { Compliance } \\
\text { CMI }\end{array}$ & $\begin{array}{l}\text { Strategic } \\
\text { CMI }\end{array}$ \\
\hline \multicolumn{7}{|l|}{ Main effect variables } \\
\hline R\&D cooperation & $\begin{array}{l}0.413 * * * \\
(0.111)\end{array}$ & $\begin{array}{l}0.323 * * * \\
(0.122)\end{array}$ & $\begin{array}{l}0.425 * * * \\
(0.110)\end{array}$ & $\begin{array}{l}0.330 * * * \\
(0.118)\end{array}$ & $\begin{array}{l}0.162 \\
(0.108)\end{array}$ & $\begin{array}{l}0.041 \\
(0.129)\end{array}$ \\
\hline External R\&D & $\begin{array}{l}0.059 \\
(0.117)\end{array}$ & $\begin{array}{l}0.011 \\
(0.127)\end{array}$ & $\begin{array}{l}0.085 \\
(0.116)\end{array}$ & $\begin{array}{l}0.108 \\
(0.125)\end{array}$ & $\begin{array}{l}-0.065 \\
(0.113)\end{array}$ & $\begin{array}{l}0.027 \\
(0.114)\end{array}$ \\
\hline Acquisition of tech & $\begin{array}{l}0.154 \\
(0.103)\end{array}$ & $\begin{array}{l}0.276^{* *} \\
(0.109)\end{array}$ & $\begin{array}{l}0.169 \\
(0.002)\end{array}$ & $\begin{array}{l}0.294 * * * \\
(0.107)\end{array}$ & $\begin{array}{l}0.109 \\
(0.099)\end{array}$ & $\begin{array}{l}0.004 \\
(0.101)\end{array}$ \\
\hline \multicolumn{7}{|l|}{ Control variables } \\
\hline Breadth & $\begin{array}{l}0.227 * * * \\
(0.064)\end{array}$ & $\begin{array}{l}0.222 * * * \\
(0.066)\end{array}$ & $\begin{array}{l}0.208 * * * \\
(0.064)\end{array}$ & $\begin{array}{l}0.191 * * * \\
(0.066)\end{array}$ & $\begin{array}{l}0.140 * * \\
(0.064)\end{array}$ & $\begin{array}{l}0.179 * * * \\
(0.063)\end{array}$ \\
\hline Breadth_sq & $\begin{array}{l}-0.013 * * \\
(0.006)\end{array}$ & $\begin{array}{l}-0.013 * * \\
(0.006)\end{array}$ & $\begin{array}{l}-0.0120^{* *} \\
(0.006)\end{array}$ & $\begin{array}{l}-0.0107^{*} \\
(0.006)\end{array}$ & $\begin{array}{l}-0.007 \\
(0.006)\end{array}$ & $\begin{array}{l}-0.008 \\
(0.006)\end{array}$ \\
\hline Internal R\&D & $\begin{array}{l}-0.092 \\
(0.148)\end{array}$ & $\begin{array}{l}-0.043 \\
(0.161)\end{array}$ & $\begin{array}{l}-0.054 \\
(0.149)\end{array}$ & $\begin{array}{l}-0.074 \\
(0.162)\end{array}$ & $\begin{array}{l}0.171 \\
(0.154)\end{array}$ & $\begin{array}{l}0.077 \\
(0.147)\end{array}$ \\
\hline SIM & $\begin{array}{l}0.242 * * \\
(0.104)\end{array}$ & $\begin{array}{l}0.377 * * * \\
(0.108)\end{array}$ & $\begin{array}{l}0.222 * * \\
(0.104)\end{array}$ & $\begin{array}{l}0.370 * * * \\
(0.108)\end{array}$ & $\begin{array}{l}0.317 * * * \\
(0.105)\end{array}$ & $\begin{array}{l}0.221 * * \\
(0.105)\end{array}$ \\
\hline Public funding & $\begin{array}{l}1.276^{* * *} \\
(0.193)\end{array}$ & $\begin{array}{l}0.947 * * * \\
(0.192)\end{array}$ & $\begin{array}{l}1.249^{* * *} \\
(0.186)\end{array}$ & $\begin{array}{l}0.963 * * * \\
(0.183)\end{array}$ & $\begin{array}{l}0.624 * * * \\
(0.147)\end{array}$ & $\begin{array}{l}0.973 * * * \\
(0.155)\end{array}$ \\
\hline Belonging to group & $\begin{array}{l}0.033 \\
(0.148)\end{array}$ & $\begin{array}{l}0.362 * * \\
(0.152)\end{array}$ & $\begin{array}{l}0.024 \\
(0.148)\end{array}$ & $\begin{array}{l}0.294^{*} \\
(0.150)\end{array}$ & $\begin{array}{l}0.300 * * \\
(0.152)\end{array}$ & $\begin{array}{l}0.055 \\
(0.153)\end{array}$ \\
\hline Size & $\begin{array}{l}0.198 * * * \\
(0.049)\end{array}$ & $\begin{array}{l}0.256^{* * *} \\
(0.055)\end{array}$ & $\begin{array}{l}0.204 * * * \\
(0.048)\end{array}$ & $\begin{array}{l}0.258 * * * \\
(0.054)\end{array}$ & $\begin{array}{l}0.220 * * * \\
(0.050)\end{array}$ & $\begin{array}{l}0.181 * * * \\
(0.050)\end{array}$ \\
\hline Market geography & $\begin{array}{l}0.023 \\
(0.070)\end{array}$ & $\begin{array}{l}0.110 \\
(0.075)\end{array}$ & $\begin{array}{l}0.028 \\
(0.069)\end{array}$ & $\begin{array}{l}0.099 \\
(0.073)\end{array}$ & $\begin{array}{l}0.068 \\
(0.068)\end{array}$ & $\begin{array}{l}-0.022 \\
(0.067)\end{array}$ \\
\hline High tech & $\begin{array}{l}-0.213 \\
(0.130)\end{array}$ & $\begin{array}{l}-0.420 * * * \\
(0.138)\end{array}$ & $\begin{array}{l}-0.158 \\
(0.129)\end{array}$ & $\begin{array}{l}-0.385^{* * *} \\
(0.137)\end{array}$ & $\begin{array}{l}-0.245^{*} \\
(0.133)\end{array}$ & $\begin{array}{l}-0.244 * \\
(0.129)\end{array}$ \\
\hline Med-high tech & $\begin{array}{l}0.006 \\
(0.101)\end{array}$ & $\begin{array}{l}0.103 \\
(0.104)\end{array}$ & $\begin{array}{l}0.043 \\
(0.101)\end{array}$ & $\begin{array}{l}0.112 \\
(0.103)\end{array}$ & $\begin{array}{l}0.159 \\
(0.0982)\end{array}$ & $\begin{array}{l}0.154 \\
(0.101)\end{array}$ \\
\hline Constant & $\begin{array}{l}-2.352^{* * *} \\
(0.258)\end{array}$ & $\begin{array}{l}-2.645^{* * *} \\
(0.285)\end{array}$ & $\begin{array}{l}-2.395 * * * \\
(0.257)\end{array}$ & $\begin{array}{l}-2.617 * * * \\
(0.279)\end{array}$ & $\begin{array}{l}-2.786^{* * *} \\
(0.270)\end{array}$ & $\begin{array}{l}-2.580 * * * \\
(0.271)\end{array}$ \\
\hline Observations & 1,023 & & 1,023 & & 1,023 & \\
\hline Log Likelihood & -801.00 & & -942.00 & & -845.0 & \\
\hline$p$-Value & 0.00 & & 0.00 & & 0.00 & \\
\hline Rho & $0.812(0.571)$ & & $0.871(0.504)$ & & $0.845(0.601)$ & \\
\hline Wald $\chi^{2}$ & 132.15 & & 125.25 & & 134.25 & \\
\hline
\end{tabular}

Notes: Standard errors are in parentheses.

$* * * p<.01, * * p<.05, * p<.1$. 
Appendix 6: Bivariate probit regressions results for inbound innovation (dual strategy vs. voluntary only), 2006-2008

\begin{tabular}{|c|c|c|c|c|c|c|}
\hline & \multicolumn{2}{|c|}{ All EI } & \multicolumn{2}{|c|}{ Production stage } & \multicolumn{2}{|c|}{ Final use stage } \\
\hline & Dual & Only_volutary & Dual & Only_voluntary & Dual & Only_voluntary \\
\hline & & & Dual CPI & Strategic CPI & Dual CMI & Strategic CMI \\
\hline \multicolumn{7}{|l|}{ Main effect variables } \\
\hline $\mathrm{R} \& \mathrm{D}$ cooperation & $\begin{array}{c}0.352 * * * \\
(0.109)\end{array}$ & $\begin{array}{l}-0.062 \\
(0.124)\end{array}$ & $\begin{array}{c}0.316^{* * * *} \\
(0.109)\end{array}$ & $\begin{array}{l}-0.0214 \\
(0.126)\end{array}$ & $\begin{array}{c}0.232 * * \\
(0.109)\end{array}$ & $\begin{array}{l}-0.0912 \\
(0.140)\end{array}$ \\
\hline External R\&D & $\begin{array}{c}0.080 \\
(0.106)\end{array}$ & $\begin{array}{c}0.010 \\
(0.119)\end{array}$ & $\begin{array}{c}0.094 \\
(0.105)\end{array}$ & $\begin{array}{l}-0.008 \\
(0.120)\end{array}$ & $\begin{array}{c}0.115 \\
(0.105)\end{array}$ & $\begin{array}{c}0.032 \\
(0.139)\end{array}$ \\
\hline Acquisition of tech. & $\begin{array}{c}0.276 * * * \\
(0.102)\end{array}$ & $\begin{array}{c}0.060 \\
(0.112)\end{array}$ & $\begin{array}{c}0.295 * * * \\
(0.101)\end{array}$ & $\begin{array}{c}0.107 \\
(0.115)\end{array}$ & $\begin{array}{c}0.150 \\
(0.102)\end{array}$ & $\begin{array}{c}0.149 \\
(0.127)\end{array}$ \\
\hline \multicolumn{7}{|l|}{ Control variables } \\
\hline Breadth & $\begin{array}{c}0.161 * * \\
(0.068)\end{array}$ & $\begin{array}{c}0.167 * * \\
(0.073)\end{array}$ & $\begin{array}{c}0.140 * * \\
(0.068)\end{array}$ & $\begin{array}{c}0.152 * * \\
(0.074)\end{array}$ & $\begin{array}{c}0.115 \\
(0.070)\end{array}$ & $\begin{array}{c}0.101 \\
(0.086)\end{array}$ \\
\hline Breadth_sq & $\begin{array}{l}-0.006 \\
(0.006)\end{array}$ & $\begin{array}{c}-0.015 * * \\
(0.006)\end{array}$ & $\begin{array}{l}-0.005 \\
(0.006)\end{array}$ & $\begin{array}{c}-0.014 * * \\
(0.006)\end{array}$ & $\begin{array}{l}-0.002 \\
(0.007)\end{array}$ & $\begin{array}{l}-0.013 * \\
(0.007)\end{array}$ \\
\hline Internal R\&D & $\begin{array}{l}-0.182 \\
(0.158)\end{array}$ & $\begin{array}{c}0.181 \\
(0.178)\end{array}$ & $\begin{array}{l}-0.122 \\
(0.159)\end{array}$ & $\begin{array}{c}0.077 \\
(0.177)\end{array}$ & $\begin{array}{c}0.046 \\
(0.164)\end{array}$ & $\begin{array}{c}0.199 \\
(0.217)\end{array}$ \\
\hline SIM & $\begin{array}{l}0.248^{* *} \\
(0.108)\end{array}$ & $\begin{array}{c}0.149 \\
(0.126)\end{array}$ & $\begin{array}{l}0.225^{* *} \\
(0.108)\end{array}$ & $\begin{array}{c}0.183 \\
(0.129)\end{array}$ & $\begin{array}{c}0.225^{* *} \\
(0.110)\end{array}$ & $\begin{array}{c}0.173 \\
(0.149)\end{array}$ \\
\hline Belonging to group & $\begin{array}{c}1.377 * * * \\
(0.168)\end{array}$ & $\begin{array}{c}-0.476 * * * \\
(0.163)\end{array}$ & $\begin{array}{c}1.345^{* * *} \\
(0.170)\end{array}$ & $\begin{array}{c}-0.436^{* *} \\
(0.163)\end{array}$ & $\begin{array}{c}0.980 * * * \\
(0.177)\end{array}$ & $\begin{array}{c}-0.797 * * * \\
(0.203)\end{array}$ \\
\hline Size & $\begin{array}{c}0.237 * * * \\
(0.051)\end{array}$ & $\begin{array}{l}-0.039 \\
(0.051)\end{array}$ & $\begin{array}{c}0.248^{* * *} \\
(0.051)\end{array}$ & $\begin{array}{l}-0.035 \\
(0.052)\end{array}$ & $\begin{array}{c}0.185^{* * *} \\
(0.051)\end{array}$ & $\begin{array}{c}0.054 \\
(0.057)\end{array}$ \\
\hline Market geography & $\begin{array}{c}0.044 \\
(0.071)\end{array}$ & $\begin{array}{c}0.047 \\
(0.074)\end{array}$ & $\begin{array}{c}0.049 \\
(0.071)\end{array}$ & $\begin{array}{c}0.036 \\
(0.076)\end{array}$ & $\begin{array}{c}0.003 \\
(0.070)\end{array}$ & $\begin{array}{l}0.149^{*} \\
(0.087)\end{array}$ \\
\hline High & $\begin{array}{c}-0.349 * * * \\
(0.135)\end{array}$ & $\begin{array}{l}-0.054 \\
(0.142)\end{array}$ & $\begin{array}{c}-0.284 * * \\
(0.134)\end{array}$ & $\begin{array}{l}-0.081 \\
(0.144)\end{array}$ & $\begin{array}{c}-0.295 * * \\
(0.136)\end{array}$ & $\begin{array}{l}-0.030 \\
(0.171)\end{array}$ \\
\hline Med-high & $\begin{array}{l}-0.013 \\
(0.104)\end{array}$ & $\begin{array}{c}0.140 \\
(0.107)\end{array}$ & $\begin{array}{c}0.032 \\
(0.104)\end{array}$ & $\begin{array}{c}0.116 \\
(0.109)\end{array}$ & $\begin{array}{c}0.108 \\
(0.104)\end{array}$ & $\begin{array}{c}0.115 \\
(0.124)\end{array}$ \\
\hline Constant & $\begin{array}{c}-2.891 * * * \\
(0.278)\end{array}$ & $\begin{array}{c}-1.416^{* * *} \\
(0.254)\end{array}$ & $\begin{array}{c}-2.978 * * * \\
(0.282)\end{array}$ & $\begin{array}{c}-1.399 * * * \\
(0.256)\end{array}$ & $\begin{array}{c}-2.861 * * * \\
(0.289)\end{array}$ & $\begin{array}{c}-2.239 * * * \\
(0.296)\end{array}$ \\
\hline
\end{tabular}

